\title{
Relative effects of precipitation variability and warming on tallgrass prairie ecosystem function
}

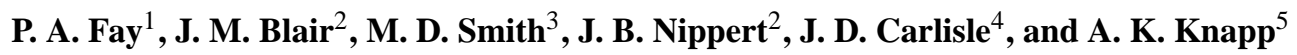 \\ ${ }^{1}$ USDA ARS Grassland Soil and Water Research Laboratory, 808 E Blackland Rd., Temple, Texas 76502, USA \\ ${ }^{2}$ Division of Biology, Kansas State University, Manhattan, Kansas 66506, USA \\ ${ }^{3}$ Department of Ecology and Evolutionary Biology, Yale University, New Haven, Connecticut 06520, USA \\ ${ }^{4}$ Utah Climate Center, Utah State University, Logan, Utah 84322, USA \\ ${ }^{5}$ Department of Biology and Graduate Degree Program in Ecology, Colorado State University, Fort Collins, Colorado 80523, \\ USA
}

Received: 1 June 2011 - Published in Biogeosciences Discuss.: 13 July 2011

Revised: 10 October 2011 - Accepted: 11 October 2011 - Published: 31 October 2011

\begin{abstract}
Precipitation and temperature drive many aspects of terrestrial ecosystem function. Climate change scenarios predict increasing precipitation variability and temperature, and long term experiments are required to evaluate the ecosystem consequences of interannual climate variation, increased growing season (intra-annual) rainfall variability, and warming. We present results from an experiment applying increased growing season rainfall variability and year round warming in native tallgrass prairie. During ten years of study, total growing season rainfall varied 2-fold, and we found $~ 50-200 \%$ interannual variability in plant growth and aboveground net primary productivity (ANPP), leaf carbon assimilation $\left(A_{\mathrm{CO}_{2}}\right)$, and soil $\mathrm{CO}_{2}$ efflux $\left(J_{\mathrm{CO}_{2}}\right)$ despite only $\sim 40 \%$ variation in mean volumetric soil water content (0$15 \mathrm{~cm}, \Theta_{15}$ ). Interannual variation in soil moisture was thus amplified in most measures of ecosystem response. Differences between years in $\Theta_{15}$ explained the greatest portion $(14-52 \%)$ of the variation in these processes. Experimentally increased intra-annual season rainfall variability doubled the amplitude of intra-annual soil moisture variation and reduced $\Theta_{15}$ by $15 \%$, causing most ecosystem processes to decrease $8-40 \%$ in some or all years with increased rainfall variability compared to ambient rainfall timing, suggesting reduced ecosystem rainfall use efficiency. Warming treatments increased soil temperature at $5 \mathrm{~cm}$ depth, particularly during spring, fall, and winter. Warming advanced canopy green up in spring, increased winter $J_{\mathrm{CO}_{2}}$, and reduced summer $J_{\mathrm{CO}_{2}}$ and forb ANPP, suggesting that the effects of warming differed in cooler versus warmer parts of the year. We conclude that (1) major ecosystem processes
\end{abstract}

Correspondence to: P. A. Fay

(philip.fay@ars.usda.gov) in this grassland may be substantially altered by predicted changes in interannual climate variability, intra-annual rainfall variability, and temperature, (2) interannual climate variation was a larger source of variation in ecosystem function than intra-annual rainfall variability and warming, and (3) effects of increased growing season rainfall variability and warming were small, but ecologically important. The relative effects of these climate drivers are likely to vary for different ecosystem processes and in wetter or drier ecosystems.

\section{Introduction}

Terrestrial ecosystems account for large exchanges of carbon (C) with the atmosphere (Denman et al., 2007), but the control of these fluxes by climate remains poorly understood. Precipitation and temperature are two primary elements of climate regulating ecosystem function. Important variation in precipitation and temperature, from an ecosystem perspective, occurs on daily to decadal time scales (Bonan, 2002; Goodin et al., 2002). Recent analyses of long-term weather records show that temperatures are warming at a rate not seen in the last century (Trenberth et al., 2007), and that areas of the Northern Hemisphere have experienced increased total annual precipitation, a greater proportion of precipitation in large events, and longer periods of drought (Groisman et al., 2005; Groisman and Knight, 2008). Projected increases in atmospheric $\mathrm{CO}_{2}$ and other greenhouse gases are expected to reinforce these trends (Karl et al., 2009). These observed and expected changes in the means and variability of precipitation and temperature on inter- and intra-annual time scales will likely have important impacts on terrestrial ecosystem

Published by Copernicus Publications on behalf of the European Geosciences Union. 
structure and function, but these have been largely unexplored.

The conceptual framework for understanding ecosystem responses to precipitation variability originates in research on arid ecosystems showing that ecosystem responses to rainfall patterns depend on the temporal separation of rainfall pulses and the extent of inactivity between pulses (NoyMeir, 1973). Soils play a crucial role by capturing discontinuous inputs of precipitation, and making it available for plant and microbial function in amounts and durations determined, in part, by soil physical properties, vegetation, and disturbance (Reynolds et al., 2004; Rodriguez-Iturbe and Porporato, 2004). Ecosystem responses to altered precipitation variability may differ among wet or dry systems or years, depending on how often thresholds of too little or too much soil moisture are exceeded (Knapp et al., 2008). For example, Heisler-White et al. (2009) found that increased growing season rainfall variability resulted in increased net primary productivity in semiarid grasslands, but decreased it in more mesic grasslands.

Previous studies in tallgrass prairie suggest that variation in precipitation at different temporal scales affects different aspects of ecosystem structure and function (Schwinning and Sala, 2004). For example, several studies have linked 2-fold or more interannual variation in aboveground net primary productivity (ANPP) to interannual variability in precipitation (Briggs and Knapp, 1995; Knapp et al., 2001; Huxman et al., 2004). Variation in the size and spacing of precipitation events within a growing season also affects numerous processes. A pattern of larger growing season rainfall events separated by longer dry intervals caused increased soil moisture variation and reduced ANPP, leaf carbon assimilation, and soil $\mathrm{CO}_{2}$ efflux compared to the same total rainfall quantity distributed in smaller more frequent events (Mielnick and Dugas, 2000; Knapp et al., 2002; Fay et al., 2003a; Harper et al., 2005; Nippert et al., 2009).

Previous studies have found varying ecosystem responses to warming. Earlier spring greenup and flowering was reported in several studies (Badeck et al., 2004; Cleland et al., 2006; Sherry et al., 2007). Increased soil respiration is generally the most commonly found response to warming (Rustad et al., 2001), but both increases (Zhou et al., 2006), decreases (Liu et al., 2009), and soil moisture-dependent responses (Almagro et al., 2009) have been reported in grasslands. Similarly, warming generally increased aboveground biomass in a cross-biome meta-analysis (Rustad et al., 2001), but studies in grassland have reported no response (de Valpine and Harte, 2001; Dukes et al., 2005; Xia et al., 2009) or decreased aboveground productivity (De Boeck et al., 2008). Varying responses to warming in grassland likely reflect complex interactions among temperature, soil water availability and the temperature and moisture sensitivities of key plant and microbial physiological processes.
The influence of interannual variability in rainfall and temperature can make it difficult to assess the effects of intraannual climatic variation (Nippert et al., 2006b). Interactions between warming and intra-annual rainfall variability may amplify interannual variation and create threshold changes in ecosystem structure (CCSP, 2010). An understanding of these interactions and their consequences for ecosystems requires long-term field experiments. Although there are longterm warming experiments (e.g. Saleska et al., 1999; An et al., 2005; Sherry et al., 2009), we know of no experiments in perennial grasslands that have manipulated growing season rainfall variability and warming for long enough to compare their effects to those of interannual climate variation. Grasslands are important and experimentally tractable systems for examining these issues because they cover approximately $40 \%$ of the land surface, are rich and dynamic in biodiversity, are a globally important agricultural resource, and are at risk from degradation and habitat conversion. Understanding the basic functional responses of grasslands to multiple climate drivers over different time scales is critical for predicting impacts of future climate regimes on grasslands and their ability to sustainably provide ecosystem goods and services, such as food, fiber, and clean water, while maintaining biological diversity (Hoekstra et al., 2005).

Here we report results from the first $10 \mathrm{yr}$ (1998-2007) of an ongoing experiment in a water-limited perennial tallgrass prairie in Kansas, in the middle of the North American Central Plains. In 1998, we began an experiment featuring an altered rainfall timing treatment that increased growing season rainfall variability, relative to ambient rainfall patterns, without changing total rainfall amount. In 2003, the increased rainfall variability regime was combined with a warming treatment. Here we extend previous studies (Knapp et al., 2002; Fay et al., 2003a; Harper et al., 2005; Nippert et al., 2009) by evaluating (1) the responsiveness of ecosystem processes to interannual climate variability vs. the responsiveness to increased within-growing season (intra-annual) rainfall variability, and (2) how the effects of increased interand intra-annual rainfall variability on ecosystem processes interact with and compare to those of experimental warming.

These objectives were addressed through measurements of the timing of plant growth and senescence, rates of plant biomass accumulation and flowering, leaf photosynthesis, and soil $\mathrm{CO}_{2}$ efflux. We hypothesized that interannual climate variability would be the primary driver of interannual variability in ANPP, while increased intra-annual rainfall variability would be the primary driver of average rates of leaf photosynthesis and soil $\mathrm{CO}_{2}$ efflux. We also hypothesized that interannual climate variability and increased intraannual rainfall variability would have stronger effects on most ecosystem processes than warming in this grassland, which is in the center of the thermal range of the dominant species. 


\section{Methods}

This study was conducted in the Rainfall Manipulation Plots (RaMPs) facility at the Konza Prairie Biological Station (KPBS) in northeastern Kansas, USA $\left(39^{\circ} 05^{\prime} \mathrm{N}, 96^{\circ} 35^{\prime} \mathrm{W}\right)$. The vegetation of the site is dominated by $\mathrm{C}_{4}$ grasses, primarily Andropogon gerardii, Sorghastrum nutans, Panicum virgatum, and Sporobolus asper, plus a number of $\mathrm{C}_{3}$ forbs, primarily Solidago canadensis, Aster ericoides, and $S$. missouriensis. The climate is temperate midcontinental. Mean annual temperature is $13^{\circ} \mathrm{C}$, mid-growing season (July) mean temperature is $27^{\circ} \mathrm{C}$ (range 20 to $33^{\circ} \mathrm{C}$ ), and mean annual precipitation is $835 \mathrm{~mm}$. Total rainfall during the biologically most active portion of the growing season (1 May through 30 September) averages $635 \mathrm{~mm}$, with the driest period during July and August. The RaMPs are located on Irwin silty clay loam soils, typical of lowland prairie in this region. The plots were burned each spring in late March, prior to green-up. Frequent fire was historically common in this grassland and today is a typical management practice (Knapp et al., 1998).

The RaMPs facility consists of twelve $14 \times 9 \mathrm{~m}$ fixedlocation rainout shelters covered from 1 May through 31 October by a clear polyethylene roof. The shelters exclude natural rainfall from the plots and divert the excluded rainfall to storage tanks for application to the plots using overhead sprinklers. Each shelter covers a hydrologically isolated $6 \times 6 \mathrm{~m}$ sampling plot. See Fay et al. (2000) for additional details on the rainout shelter design.

\subsection{Treatments}

During Phase I, 1998-2001, four experimental rainfall treatments were applied in three replicates. The treatments were factorial combinations of two growing season rainfall quantities combined with two growing season rainfall patterns, as follows:

- Ambient: each time a natural rainfall event occurred, the quantity of rain that fell was applied to the plots within $24 \mathrm{~h}$, replicating the naturally occurring rainfall regime in number and sizes of rainfall events, length of dry intervals between events, and total growing season amount.

- Reduced quantity: as in ambient, except $70 \%$ of each rainfall event was applied.

- Altered pattern: intra-annual rainfall variability was increased by accumulating the collected rainfall until the dry interval was $50 \%$ longer than the ambient dry interval. Then the accumulated rainfall was applied as a single large event, at a rate that insured all rainfall entered the soil profile. The total growing season amount of rainfall applied in this treatment was identical to ambient, while the number of rain events was reduced and the size of rain events and length of dry intervals were increased.

- Reduced quantity and altered pattern: as in altered pattern, except only $70 \%$ of the accumulated rainfall was applied, which imposed both drought and increased rainfall variability.

All rainfall application amounts were reduced by $10 \%$ from the nominal ambient amount to offset slight increases in soil moisture underneath the rainout shelters compared to the adjacent unsheltered control plots. In 2002, the reduced quantity treatment was discontinued as a transition to prepare for Phase II. All plots continued to receive their assigned rainfall timing treatment (ambient vs. altered) but all now received growing season rainfall amounts equivalent to $100 \%$ of ambient, $n=6$ per rainfall treatment.

Phase II began in 2003 with the initiation of a warming treatment. Infrared heating lamps (HS-2420, Kalglo Electronics Co, Bethlehem, PA, USA) were installed in two randomly chosen $2 \times 2 \mathrm{~m}$ subplots within the $6 \times 6 \mathrm{~m}$ rainfall treatment plots. The lamps were operated continuously year round, and emitted a constant $20-25 \mathrm{~W} \mathrm{~m}^{-2}$ of downward infrared radiation. Lamps were placed $1.2 \mathrm{~m}$ above the soil surface at the beginning of each growing season and raised periodically to maintain that height above the plant canopy. The lamps are identical to those of other grassland warming experiments (Luo et al., 2001), and here increased day $\left(0.4-0.6^{\circ} \mathrm{C}\right)$ and night $\left(1.0-1.5^{\circ} \mathrm{C}\right)$ canopy temperatures of a $2 \times 2 \mathrm{~m}$ area during May through August. Two additional $2 \times 2 \mathrm{~m}$ subplots were unwarmed and thus experienced ambient temperatures. One unwarmed subplot contained a dummy lamp to control for effects from the physical presence of the lamps and associated infrastructure.

\subsection{Microclimate and ecosystem function measurements}

Sensors were installed to measure rainfall, soil temperature, and soil water content. Natural rainfall quantities were measured with six manual rain gauges. Soil temperature was measured with thermocouples at $5 \mathrm{~cm}$ depth $\left(T_{\text {soil }_{05}}\right)$ in two ambient and two altered rainfall plots during 1998-2003, and in the center of each of the four subplots in three ambient and three altered plots during 2004-2007. $T_{\text {soil }}$ was logged every $30 \mathrm{~min}$ and stored as $1 \mathrm{~h}$ averages on data loggers (CR10X, Campbell Scientific, Logan, UT, USA).

Soil volumetric water content at $0-15 \mathrm{~cm}$ depth $\left(\Theta_{15}\right)$ was measured using time domain reflectometry methods. Probes consisting of a pair of $15 \mathrm{~cm}$ long stainless steel rods were inserted vertically at the soil surface at four locations per plot (Phase I), or in the center of each subplot (Phase II). During 1998-2004, these probes were read weekly using a Tektronix cable tester. Beginning in 2005, $\Theta_{15}$ was measured with $30 \mathrm{~cm}$ long probes (CS616, Campbell Scientific, Logan, UT, USA) inserted at $30^{\circ}$. $\Theta_{15}$ was logged every $10 \mathrm{~min}$ and 
stored as $30 \mathrm{~min}$ averages on data loggers. We used the daily average $\Theta_{15}$ of one day per week from the continuous data to match the sampling frequency of the pre-2005 $\Theta_{15}$ data.

\subsection{Plant growth measurements}

\subsubsection{Canopy greenness}

Spring canopy green up and fall canopy senescence was quantified in the 2005-2007 growing seasons by measuring percent green cover with a digital canopy camera (First Growth, Decagon Devices Inc., Pullman, WA, USA). Each subplot was imaged between 09:00 and 12:00 LT every four to seven days following the first appearance of new spring growth ( late April) until canopy closure (mid-late June), and from the onset of canopy decline until frost ( late August-October). Percent green cover was estimated by a proprietary algorithm in the camera processor, which estimated the ratio of green pixels to total pixels in the image. The camera was calibrated with a white card prior to each sampling, to control for variation in illumination among sample dates.

\subsubsection{Canopy light penetration}

Light interception by the canopy was determined at midseason as a proxy of accumulated midseason aboveground biomass. Vertical profiles of photosynthetic photon flux density (PPFD) were measured with a ceptometer (Decagon Devices Inc., Pullman, WA, USA) at $10 \mathrm{~cm}$ increments to the maximum canopy height $(<1 \mathrm{~m})$. Profiles were measured between 12:00 and 14:00 at two locations per plot during 1999-2002, and one location per subplot during 2003-2007 on 2-4 clear days each July. Light profiles were fit with a sigmoid equation:

$\operatorname{PPFD}=a /\left(1-e^{\left(x-x_{0}\right) / b}\right)$

where $a=$ maximum PPFD, $x_{0}=$ height of $50 \%$ PPFD and $b=$ slope of PPFD decrease. Smaller $x_{0}$ values indicate that the height of interception of $50 \%$ of the light is closer to the ground, and deeper penetration of light into the canopy means less aboveground biomass. Seven out of 300 profiles did not fit this equation at $p<0.0001$, and were omitted from analysis.

\subsubsection{Aboveground net primary productivity}

ANPP was estimated annually from harvests of aboveground biomass at the end of the growing season (mid October). All aboveground biomass was clipped at ground level from $20 \times 50 \mathrm{~cm}$ sampling quadrats. Ten quadrats per plot were harvested during 1998-2002, and four quadrats per subplot (16 per plot) were harvested during 2003-2007. The plots were burned each spring and ungrazed, so accumulated aboveground biomass represented current year production. Harvested samples were sorted into grasses and forbs, and weighed after drying at $65^{\circ} \mathrm{C}$ for at least $48 \mathrm{~h}$. One plot differed markedly in plant species composition from the others and was omitted from the biomass analyses. Data from 1998-2002 were reported in Knapp et al. (2002) and Fay et al. (2003a).

\subsubsection{Flowering}

Flowering culms of Andropogon gerardii and Sorghastrum nutans were counted each September in two locations per plot during 1999-2002, and once per subplot during 20032007.

\subsection{Measurements of $\mathrm{CO}_{2}$ fluxes}

\subsubsection{Leaf photosynthesis}

Leaf net photosynthesis $\left(A_{\mathrm{CO}_{2}}\right)$ was measured weekly from June through September in 1998 and 1999, and one to three times per month in June, July, and August in 2000, 2002, and 2005-2006 on A. gerardii. Solidago canadensis was also measured during 1998-2000, and S. nutans was measured in 2002, 2005 and 2006. Sampling dates were chosen to capture the full range of growing season soil moisture variability.

$A_{\mathrm{CO}_{2}}$ during 1998-2002 was measured with two annually calibrated closed path infrared gas analyzers (LI-6200, LICor Biosciences, Lincoln, NE, USA). $A_{\mathrm{CO}_{2}}$ was measured on four plants per plot, using fully expanded, recently matured upper canopy leaves, and was completed between 10:00 h15:00 h. The 1998-1999 weekly measurements usually were conducted on cloud-free days. Measurements were omitted from analysis if PPFD was $<500 \mu \mathrm{mol} \mathrm{m}^{-2} \mathrm{~s}^{-1}$, and entire plots were omitted from analysis when plot mean PPFD was $<1000 \mu \mathrm{mol} \mathrm{m}^{-2} \mathrm{~s}^{-1}$. This data filtering resulted eliminated $7 \%$ (244 out of 3488 ) measurements. All measurements during 2000 and 2002 were conducted on clear days.

$A_{\mathrm{CO}_{2}}$ during 2005-2006 was measured with two open path infrared gas analyzers (LI-6400, LI-Cor, Biosciences, Lincoln, NE, USA) with red/blue LED light sources and $\mathrm{CO}_{2}$ injectors. Measurements were conducted in one warmed subplot and one unwarmed subplot per plot. Each measurement used one recently matured leaf per tiller from two tillers per species. Cuvette conditions were $1500 \mu \mathrm{mol} \mathrm{m}^{-2} \mathrm{~s}^{-1} \mathrm{PPFD}$, $370 \mu \mathrm{mol} \mathrm{mol}^{-1}\left(\mathrm{CO}_{2}\right)$, and near ambient relative humidity. This PPFD is adequate for light saturation and comparable to light levels in the 1998-2002 data. Measurements were logged when stability (the coefficient of variation of $A_{\mathrm{CO}_{2}}$ ) was $<1 \%$ over $15 \mathrm{~s}$. Measurements usually stabilized in 510 min. Data from 1999 were reported in Fay et al. (2002), and from 2005-2006 in Nippert et al. (2009).

\subsubsection{Soil $\mathrm{CO}_{2}$ fluxes}

Soil $\mathrm{CO}_{2}$ efflux $\left(J_{\mathrm{CO}_{2}}\right)$ was measured with an infrared gas analyzer (LI-6200, LI-Cor Biosciences Inc., Lincoln, NE). During the growing season, $J_{\mathrm{CO}_{2}}$ was measured weekly 
each May through October. Winter $J_{\mathrm{CO}_{2}}$ was measured on 7-9 snow-free dates during November through March in 2005/2006 and 2006/2007. $J_{\mathrm{CO}_{2}}$ was measured at two permanently installed PVC collars ( $8 \mathrm{~cm}$ diam, $1.7 \mathrm{~cm}$ height inserted to $1.2 \mathrm{~cm}$ ) at four locations per plot during 1998-2002, and at two collars per subplot from 2003-2007. Data from 1998-2001 were reported in Harper et al. (2005). $J_{\mathrm{CO}_{2}}$ rates were estimated from the linear rise in $\mathrm{CO}_{2}$ concentration over 1 to $3 \mathrm{~min}$.

\subsection{Data analysis}

Intra-annual rainfall variability was quantified by computing the coefficient of variation (CV) from the daily rainfall amounts applied to the RaMPs during the growing season (1 May-30 September). Mean growing season $\Theta_{15}$ was computed by averaging the weekly measurements for each year. Variability during the growing season in $\Theta_{15}$ was quantified by computing two variability metrics: (1) the $\mathrm{CV}$ of $\Theta_{15}$, which expresses temporal variability in mean $\Theta_{15}$ as a percentage of $\Theta_{15}$; (2) the mean change in soil moisture between successive individual rainfall events $\left(\Delta \Theta_{15}\right)$, which describes the absolute amplitude of variation in $\Theta_{15}$.

Statistical analyses of soil moisture and ecosystem process responses to treatments and year were conducted using linear mixed models procedures in SAS 9.1 (SAS Institute Inc, 2003) in two steps. First, a repeated measures model was fit to data from all ten years with rainfall pattern (ambient vs. altered) as a fixed effect in a randomized complete block design (RCB), year as the repeated effect, and plot as the experimental unit. Type III sums of squares were used to orthogonally compare the effect of interannual climate variability versus effects of increased intra-annual rainfall variability.

Second, separate repeated measures models were fit to the two phases of the experiment. The model for Phase I (19982002) contained rainfall pattern and quantity and their interaction as fixed effects in RCB, year as the repeated effect, and plot as the experimental unit. Type III sums of squares were again used to compare effects of interannual climate variation against effects of intra-annual variability and quantity treatments. The model for Phase II (2003-2007) contained rainfall pattern as a whole-plot fixed effect in RCB, warming as a subplot fixed effect, and year as the repeated effect. This model compared interannual climate variation to increased rainfall variability and warming effects. For responses measured multiple times during the growing season (i.e. soil moisture means and variability, midseason biomass, $A_{\mathrm{CO}_{2}}, J_{\mathrm{CO}_{2}}$ ), the growing season mean was used for analysis, calculated by averaging values from individual sample dates in each year. Transformations were applied to response variables where needed to meet assumptions of normality and/or equal variances. Means separations were performed using the LSMEANS statement with the DIFF option. Full ANOVA results are presented in the Appendix (Tables A1, A2).
We used multiple regression (MR) analysis to determine which among mean $\Theta_{15}, \mathrm{CV}_{\Theta_{15}}$, or $T_{\text {soil }}$ es explained more variation in key ecosystem responses. Grass and forb ANPP, $A_{\mathrm{CO}_{2}}$, and $J_{\mathrm{CO}_{2}}$ were analyzed with a stepwise procedure with $p=0.10$ required for variable retention. Variance inflation factors for the predictor variables ranged from 1.2 $\left(T_{\text {soil }_{05}}\right)$ to $1.7\left(\mathrm{CV}_{\Theta_{15}}\right)$, suggesting that multicollinearity among the predictor variables was low. Univariate regression analyses of these variables were also conducted.

\section{Results}

\subsection{Microclimate}

\subsubsection{Rainfall}

Total growing season rainfall inputs (May-September) varied 1.8-fold between years, from $334 \mathrm{~mm}$ in 2005 to $600 \mathrm{~mm}$ in 1998 (Fig. 1a). The altered rainfall treatment dramatically changed growing season rainfall regimes. Event sizes were larger, small events became infrequent, and dry intervals increased compared to the ambient rainfall pattern (Fig. 1b). As a result, the $\mathrm{CV}$ of individual rainfall events was significantly greater in 9 out of $10 \mathrm{yr}$ in the altered treatment compared to ambient (Fig. 1c, $p<0.0001$, Table A1). The reduced quantity treatment during Phase I caused only minor though significant $(p=0.01)$ variation in rainfall $\mathrm{CV}$.

\subsubsection{Mean soil moisture}

There were significant differences among years in growing season mean soil moisture. Under ambient rainfall, $\Theta_{15}$ ranged from $27 \%$ in 2002 to $38 \%$ in 1999 (Fig. 1d, $p<0.0001$, Table A1). Altered rainfall patterns reduced $\Theta_{15}$ to about $86 \%$ of ambient values for the $10 \mathrm{yr}$ combined ( $p=0.0025$ ), even though the treatments received the same total rainfall amounts. The reduced quantity treatment reduced $\Theta_{15}$ to $90 \%$ of ambient values $(p=0.01)$, similar to the magnitude of the altered rainfall effect. $\Theta_{15}$ was marginally reduced $(p=0.094)$ in warmed compared to unwarmed subplots, due to significant differences in 2006 $(1.9 \%, p=0.009)$ and $2007(1.8 \%, p=0.01)$.

\subsubsection{Soil moisture variability}

Altered rainfall patterns increased $\mathrm{CV}_{\Theta_{15}}(16 \%)$ and $\Delta \Theta_{15}$ (2-fold) (Fig. 1e, $p<0.01$, Table A1), indicating greater soil moisture variability during the growing season and a greater amplitude of soil moisture change between sequential rainfall events. $\mathrm{CV}_{\Theta_{15}}$ was a decreasing function of $\Theta_{15}$ (Fig. 2, $R^{2}=0.38, p<0.0001$ ), indicating that lower mean soil moisture was often accompanied by greater growing season soil moisture variability. $\Delta \Theta_{15}$ was weakly correlated with $\Theta_{15}$ $\left(R^{2}=0.07, p<0.0001\right)$, indicating that the amplitude of soil moisture change between events was only loosely associated 

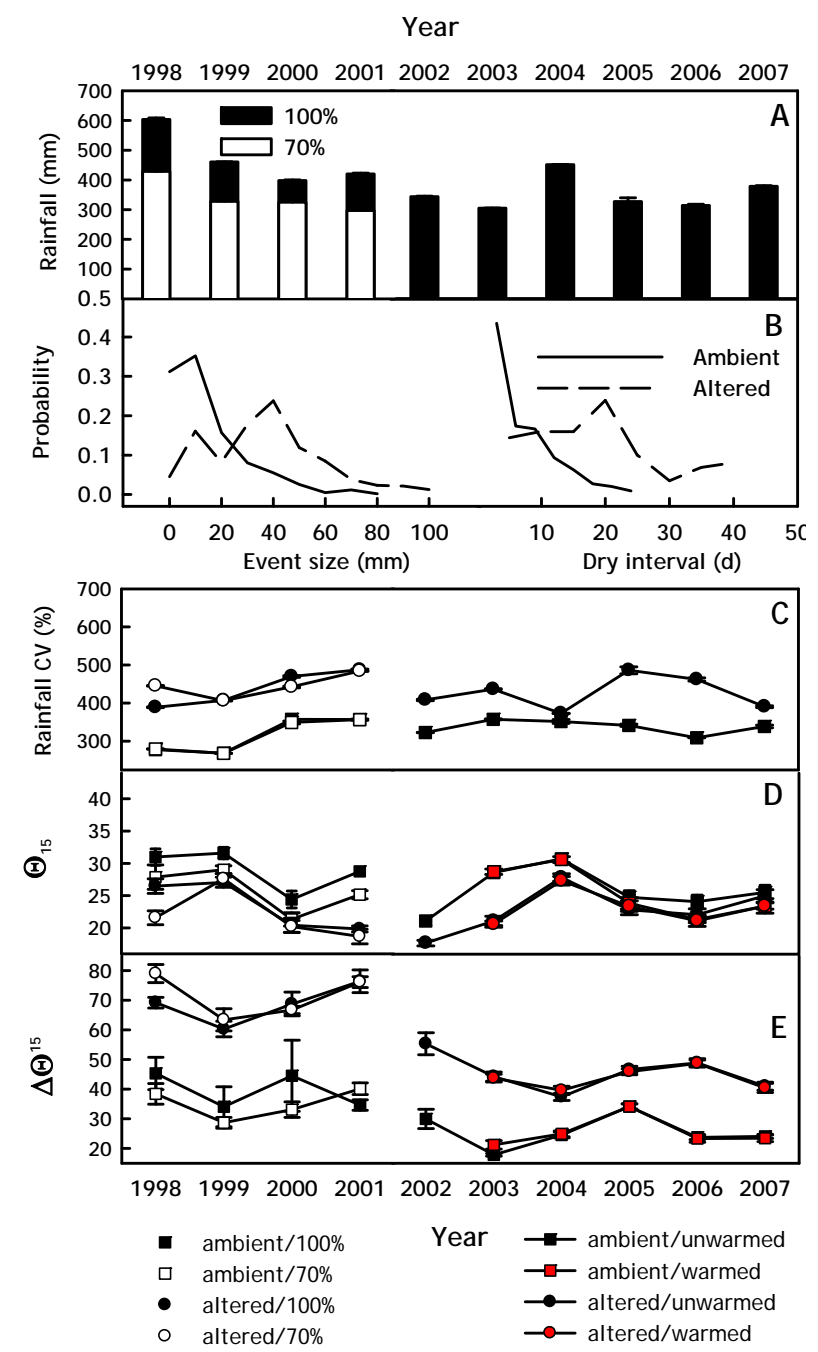

Fig. 1. Annual rainfall inputs and soil moisture means and variability in the RaMPs experiment during the rainfall pattern $x$ quantity treatments (Phase I, 1998-2001) and the rainfall pattern $x$ warming treatments (Phase II, 2003-2007). (A) Total growing season rainfall. (B) Probability density functions of individual rainfall event size (100\% treatments) and dry interval length. (C) Coefficient of variation $(\mathrm{CV})$ of daily rainfall inputs during the growing season. (D) Mean volumetric soil water content for $0-15 \mathrm{~cm}\left(\Theta_{15}\right)$. (E) Mean change in $\Theta_{15}$ between successive rainfall events $\left(\Delta \Theta_{15}\right)$. Error bars denote one SE.

with mean soil moisture, and likely more dependent on rain event size. $\Delta \Theta_{15}$ and $C V_{\Theta_{15}}$ were unaffected by reduced rainfall quantity $\left(0.06<p<0.19\right.$, Table A1) and $\Delta \Theta_{15}$ was unaffected by warming $(p=0.23)$.

\subsubsection{Soil temperature}

$T_{\text {soii }}{ }_{05}$ differed significantly among years (Fig. 3a, $p<0.0001$, Table A1), varying by $3{ }^{\circ} \mathrm{C}$ during 2004 2007. However, $T_{\text {soil }_{05}}$ varied considerably more among seasons than among years. Winter $T_{\text {soil }}$ as averaged $2-4{ }^{\circ} \mathrm{C}$,

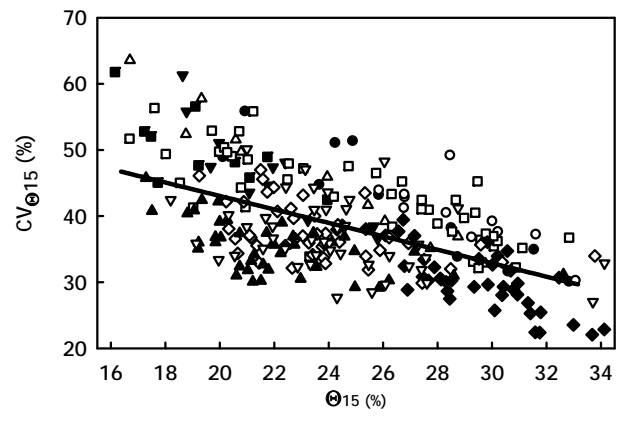

Fig. 2. Association between growing season mean volumetric soil water content for $0-15 \mathrm{~cm}\left(\Theta_{15}\right)$ and its coefficient of variation $\left(\mathrm{CV}_{\Theta_{15}}\right)$. Each point represents a plot, and symbols denote different years.

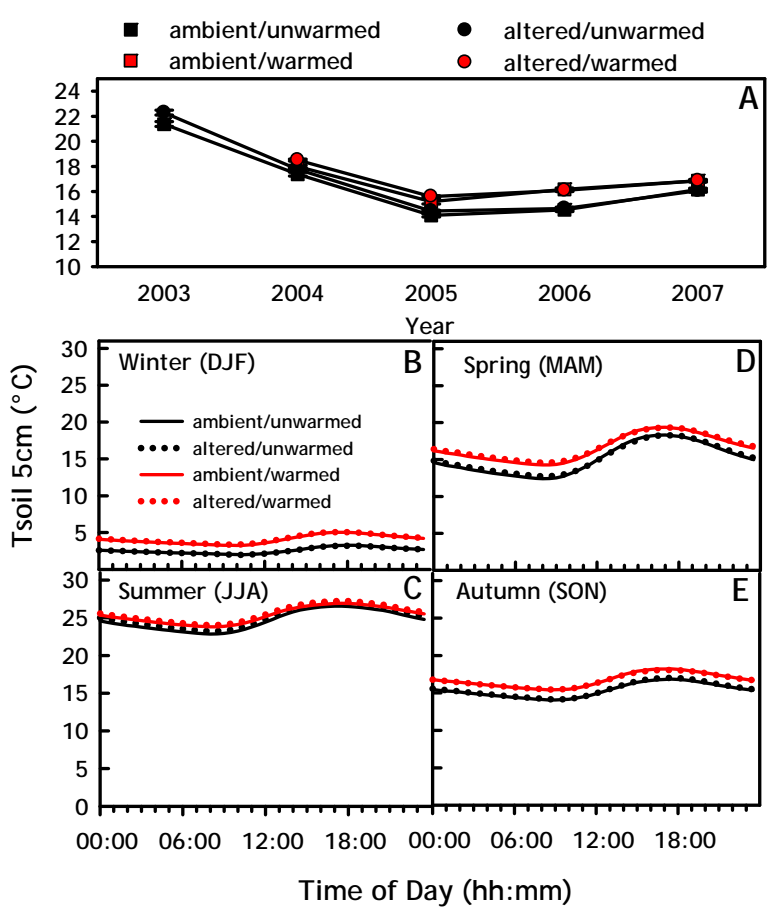

Fig. 3. Soil temperature at $5 \mathrm{~cm}$ depth $\left(T_{\text {soil }_{05}}\right)$ by rainfall pattern and warming treatment during 2003-2007. (A) Mean annual soil temperature, error bars denote 1 SE. (B-E) Diurnal variation in $T_{\text {soil }_{05}}$ for each season.

increasing to $15-17^{\circ} \mathrm{C}$ during spring and fall, and $24-26^{\circ} \mathrm{C}$ during summer (Fig. $3 \mathrm{~b}-\mathrm{e}$ ). $T_{\text {soil }} 1_{05}$ differed $2-3^{\circ} \mathrm{C}$ between day and night, regardless of season.

The warming treatment caused a $1{ }^{\circ} \mathrm{C}$ overall increase in mean annual $T_{\text {soil }_{05}}$ during 2004-2007 (Fig. 3a, $p<0.0001$, Table A1), with the increase varying from $0.7^{\circ} \mathrm{C}$ in 2004 to $1.5^{\circ} \mathrm{C}$ in $2006(p<0.0001)$. Warming caused larger increases in $T_{\text {soil }} 05$ during fall, winter and spring $\left(1.3-1.6^{\circ} \mathrm{C}\right)$ compared to summer $\left(0.7^{\circ} \mathrm{C}\right.$, all $p<0.0001$, Fig. $\left.3 \mathrm{~b}-\mathrm{e}\right)$. Warming effects on $T_{\text {soil } 05}$ were similar day and night. 


\subsection{Plant growth responses}

\subsubsection{Canopy greenness}

Warming was the largest factor affecting canopy green up during spring. During late April and May (weeks 15-20) when green up was most rapid, warming increased greenness by $13-96 \%$ compared to unwarmed subplots (Fig. 4, $p<0.0001$, Table A2). Differences among years in canopy greenness were highly significant $(p<0.0001)$ but much smaller (3\%, data not shown) than the effect of warming. Altered rainfall patterns caused no significant effects on greenness during weeks 15-20 ( $p=0.34)$. However, as the season progressed (early June, weeks 20-22), the warming effect diminished and altered rainfall patterns reduced greenness $\sim 8 \%$ compared to ambient rainfall $(p=0.0079)$. Canopy senescence in the late summer/fall showed small but significant $(p<0.0001)$ differences among years, but no significant warming or rainfall effects (Table A2).

\subsubsection{Midseason aboveground biomass}

There were large differences among years in canopy light levels at midseason $\left(x_{0}\right.$, height of interception of $50 \%$ of the light), a direct measure of canopy structure and a proxy for aboveground biomass. Across all years, $x_{0}$ varied almost 2fold (Fig. 5a, $p<0.0001$, Table A2), while altered rainfall patterns reduced $x_{0} 17 \%(p=0.016)$, indicating less aboveground biomass at midseason. Altered rainfall reduced $x_{0}$ in all years during Phase I $(p=0.04)$, while during Phase II $x_{0}$ was significantly reduced in 2004 and $2005(p<0.001)$. Warming only affected $x_{0}$ in 2007, increasing it by $15 \%$ $(p=0.0002)$.

\subsubsection{Aboveground net primary productivity}

For all years combined, total ANPP varied 2-fold among years (Fig. 5b, $p<0.0001$, Table A2), while altered rainfall reduced total ANPP by an average of $10 \%$ compared to ambient rainfall ( $p=0.0098$, Table A2). During Phase I, altered pattern and reduced quantity treatments both reduced total ANPP by $15 \%$ compared to ambient $(0.004<p<0.03$, Table A2). However, total ANPP was not affected by altered rainfall patterns during Phase II ( $p \geq 0.12)$. Warming caused $\mathrm{a} \sim 5 \%$ reduction in Phase II ANPP $(p<0.039)$.

Grass ANPP accounted for $80 \%$ of total ANPP and varied to a similar degree among years $(p<0.0001$, Fig. $5 c)$. Grass ANPP was not affected by altered rainfall patterns, but increased in 2007 in response to warming ( $p=0.017$, Table A2). Forb ANPP showed little variation among years except for an increase in 2007 (Fig. 5d, $p<0.0001$, Table A2). Warming had the strongest effects on forb ANPP, reducing it $23 \%$ compared to unwarmed subplots $(p=0.04)$, with no significant difference in warming effects among years $(p=0.91)$. There were no significant effects of rainfall treatments on forb ANPP $(p>0.40)$.

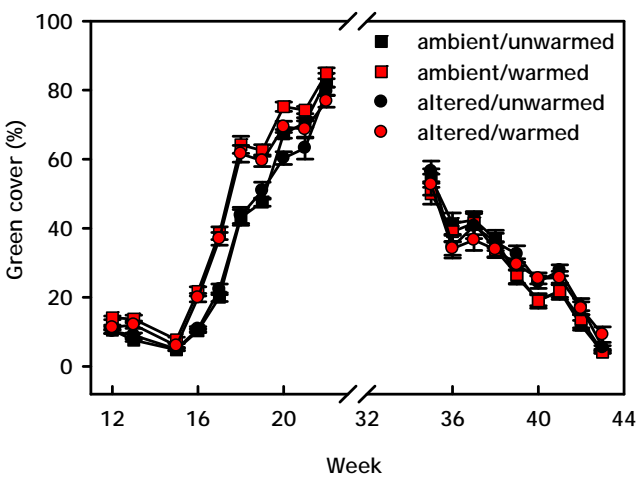

Fig. 4. Cover of green vegetation (\%) during spring and fall, by rainfall pattern and warming treatment during 2005-2007. Error bars denote $1 \mathrm{SE}$.

\subsubsection{Flowering}

Flowering culm production in A. gerardii and $S$. nutans was low in most years but was abundant in 1999 and 2004 (Fig. 5e-f, $p<0.0001$, Table A2). A. gerardii flowering did not differ between rainfall or warming treatments $(0.16<p<0.70$, Table A2). In contrast, altered rainfall patterns reduced $S$. nutans flowering by $50 \%$ for all years combined $(p=0.0036)$, as well as in both Phase I and II $(0.006<p<0.04$, Table A2). Warming treatments had no effects on flowering culm production for $S$. nutans.

\subsection{Plant and soil $\mathrm{CO}_{2}$ flux responses}

\subsubsection{Leaf carbon assimilation}

There were large differences among years in $A_{\mathrm{CO}_{2}}$ for the codominant grasses $A$. gerardii and $S$. nutans. Mean $A_{\mathrm{CO}_{2}}$ in A. gerardii varied 3-fold among years (Fig. 6a, $p<0.0001$, Table A1), and was reduced $8 \%$ by altered rainfall patterns for all years combined ( $p=0.03$ ) because of significant effects in 1998, 2000, and 2002. During Phase I, A. gerardii $A_{\mathrm{CO}_{2}}$ was unaffected by the reduced quantity treatment (data not shown, $p>0.46$, Table A1). For $S$. nutans, $A_{\mathrm{CO}_{2}}$ varied $80 \%$ among years (Fig. 6b, $p<0.0001$ ), and was reduced by altered rainfall patterns in $2002(p=0.007)$. Warming had no effect on $A_{\mathrm{CO}_{2}}$ for either grass. In contrast, $S$. canadensis showed little interannual variation in $A_{\mathrm{CO}_{2}}$ and no response to altered rainfall patterns. However, the reduced quantity treatment decreased S. canadensis $A_{\mathrm{CO}_{2}}$ by $10 \%$ compared to ambient quantity ( $p<0.05$, Table A1), mainly because of a large decrease in 2000 (Fig. 6b). For all three species, $\Theta_{15}$ was reduced by 8 to $38 \%(0.07>p>0.0001)$ in years when alterations in rainfall timing and/or quantity caused significant reductions in $A_{\mathrm{CO}_{2}}$.

\subsubsection{Soil $\mathrm{CO}_{2}$ fluxes}

Mean growing season $J_{\mathrm{CO}_{2}}$ varied by $46 \%$ among years, $(p<0.0001$, Fig. 7a, Table A1). Altered rainfall patterns 


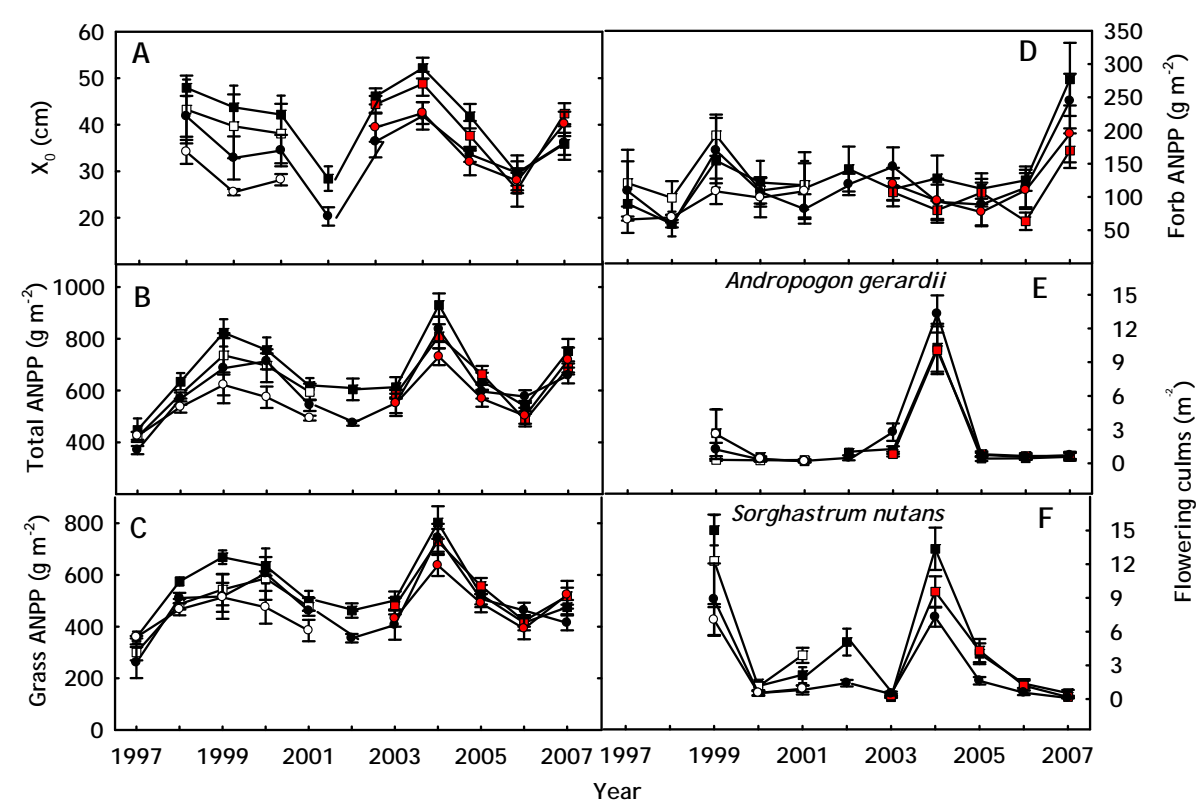

Fig. 5. Plant growth by year in the rainfall pattern and warming treatments, error bars denote 1 SE. Symbols as in Fig. 1. (A) Canopy light interception $\left(x_{0}\right)$, the height in the canopy receiving $50 \%$ of incoming light, a proxy for aboveground biomass. (B) Total, (C) grass and (D) forb ANPP. Flowering culm production in the dominant $\mathrm{C}_{4}$ grasses (E) Andropogon gerardii and (F) Sorghastrum nutans .

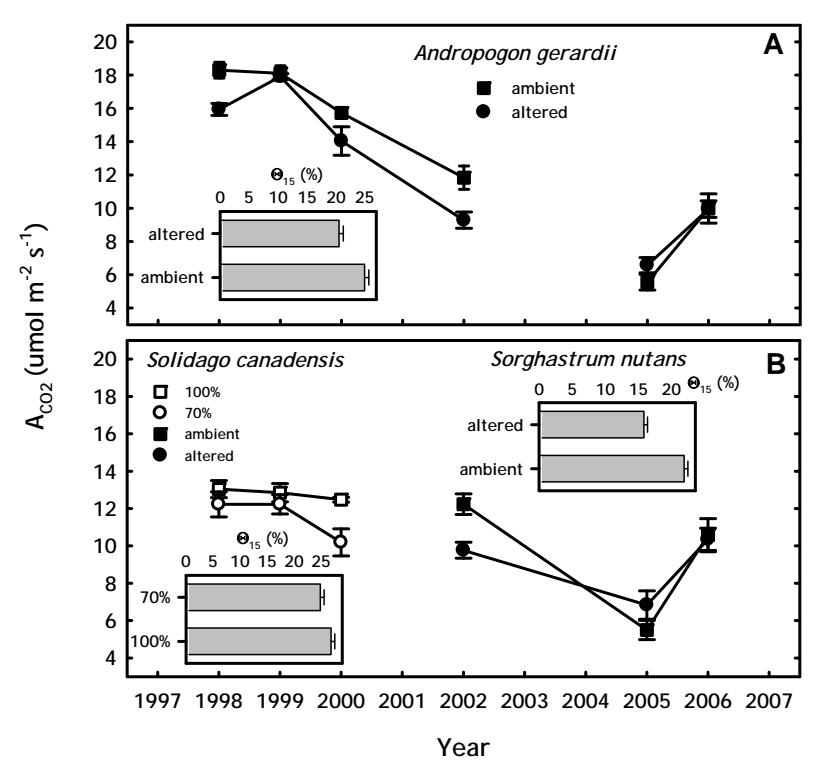

Fig. 6. Leaf photosynthesis $\left(A_{\mathrm{CO}_{2}}\right)$ by rainfall treatment for (A) Andropogon gerardii $\left(\mathrm{C}_{4}\right)$ and $(\mathbf{B})$ Sorghastrum nutans $\left(\mathrm{C}_{4}\right)$, and Solidago canadensis $\left(\mathrm{C}_{3}\right)$. Insets: mean $0-15 \mathrm{~cm}$ volumetric soil water content $\left(\Theta_{15}\right)$ for years when altered rainfall caused significant reductions in $A_{\mathrm{CO}_{2}}$. Error bars denote $1 \mathrm{SE}$ of the mean.

reduced $J_{\mathrm{CO}_{2}}$ by $8 \%(p=0.0005)$, with similar reductions each year $(p=0.18)$. During Phase I, altered rainfall reduced $J_{\mathrm{CO}_{2}}$ by $13 \%$ (Fig. $7 \mathrm{~b}, p<0.0001$ ), while the reduced quantity treatment caused a $7 \%$ decrease $(p=0.032)$. During Phase II, altered rainfall patterns marginally reduced $J_{\mathrm{CO}_{2}}$ compared to ambient rainfall (Fig. 7c, $p=0.08$ ), and warm- ing reduced $J_{\mathrm{CO}_{2}}$ by $5 \%$ compared to ambient $(p=0.04)$. $J_{\mathrm{CO}_{2}}$ was much lower during winter than during the growing season, and increased $11 \%$ with warming ( $p=0.003$, Fig. 7 d). Winter $J_{\mathrm{CO}_{2}}$ was unaffected by altered growing season rainfall patterns.

\subsubsection{Correlations with soil moisture and temperature}

Total and grass ANPP, $J_{\mathrm{CO}_{2}}$, and $A_{\mathrm{CO}_{2}}$ for all three species increased with $\Theta_{15}\left(0.14<R^{2}<0.52,0.0001<p<0.003\right.$, Fig. 8a-c, Table 1), while forb ANPP was not correlated with $\Theta_{15}(p=0.48)$. Grass ANPP and $J_{\mathrm{CO}_{2}}$ decreased with $\mathrm{CV}_{\Theta_{15}}, \quad\left(R^{2}=0.04-0.22,0.0001<p<0.01\right.$ Fig. 8d-e $)$. $A_{\mathrm{CO}_{2}}$ was not correlated with $\mathrm{CV}_{\Theta_{15}}$ for any of the species, although the variability in $A_{\mathrm{CO}_{2}}$ decreased with $\mathrm{CV}_{\Theta_{15}}$ (Fig. 8f). $A_{\mathrm{CO}_{2}}$ in A. gerardii and $S$. nutans were increasing functions of $T_{\text {soil }_{05}}\left(R^{2}=0.04-0.12,0.007<p<0.04\right.$, data not shown).

$\Theta_{15}$ was the first variable to enter multiple regression models for total ANPP, grass ANPP, and $A_{\mathrm{CO}_{2}}$, accounting for $18-52 \%$ of the variation $(0.0001<p<0.009$, Table 1). $\mathrm{CV}_{\Theta_{15}}$ was the second variable to enter the MR model for grass and forb ANPP, and A. gerardii $A_{\mathrm{CO}_{2}}$, explaining an additional $2-7 \%$ of variation in these variables $(0.0001<p<0.003) . \quad \mathrm{CV}_{\Theta_{15}}$ did not enter models for $A_{\mathrm{CO}_{2}}$ of $S$. canadensis or $S$. nutans. Thus, $\Theta_{15}$ consistently explained more of the variation in these ecosystem processes. $J_{\mathrm{CO}_{2}}$ followed a different pattern. $\mathrm{CV}_{\Theta_{15}}$ was first to enter the MR model $\left(R^{2}=0.27, p<0.0001\right)$ followed by $\Theta_{15}\left(R^{2}=0.11, p<0.0001\right)$. $T_{\text {soil }_{05}}$ entered the MR models last or not at all, accounting for only $1-6 \%$ of 
Table 1. Regression parameters and statistics for mean soil moisture at $15 \mathrm{~cm}$ depth $\left(\Theta_{15}\right)$, intra-annual season soil moisture variability at $15 \mathrm{~cm}$ depth $\left(\mathrm{CV}_{\Theta_{15}}\right)$, and soil temperature at $5 \mathrm{~cm}$ depth $\left(T_{\text {soil }_{05}}\right)$ from univariate and multivariate regression models for ANPP, leaf photosynthesis, and soil $\mathrm{CO}_{2}$ efflux.

\begin{tabular}{|c|c|c|c|c|c|c|c|c|c|c|c|}
\hline & & \multicolumn{5}{|c|}{ Univariate Regression } & \multicolumn{5}{|c|}{ Multiple Regression } \\
\hline & & & Intercep & Slope & $R^{2}$ & $p$ & & Partial $R^{2}$ & Model $R^{2}$ & $F$ & $p$ \\
\hline \multirow{9}{*}{ ANPP } & \multirow{3}{*}{ Total } & $\Theta_{15}$ & 279.0 & 1480.0 & 0.16 & $<0.0001$ & $\Theta_{15}$ & 0.19 & 0.19 & 44.9 & $<0.0001$ \\
\hline & & $\mathrm{CV}_{\Theta_{15}}$ & 890.0 & -6.4 & 0.10 & $<0.0001$ & $\mathrm{CV}_{\Theta_{15}}$ & - & - & - & \\
\hline & & $T_{\text {soil }_{05}}$ & - & - & - & $<0.11$ & $T_{\text {soil }_{05}}$ & 0.02 & 0.21 & - & 0.0192 \\
\hline & \multirow{3}{*}{ Grass } & $\Theta_{15}$ & 118.0 & 1621.0 & 0.18 & $<0.0001$ & $\Theta_{15}$ & 0.18 & 0.18 & 41.6 & $<0.0001$ \\
\hline & & $\mathrm{CV}_{\Theta_{15}}$ & 831.0 & -8.1 & 0.15 & $<0.0001$ & $\mathrm{CV}_{\Theta_{15}}$ & - & - & - & \\
\hline & & $T_{\text {soil }_{05}}$ & - & - & - & 0.15 & $T_{\text {soil }_{05}}$ & 0.105 & 0.20 & 3.6 & 0.0576 \\
\hline & \multirow{3}{*}{ Forb } & $\Theta_{15}$ & - & - & - & 0.32 & $\Theta_{15}$ & - & - & - & - \\
\hline & & $\mathrm{CV}_{\Theta_{15}}$ & 59.5 & 1.7 & 0.01 & 0.02 & $\mathrm{CV}_{\Theta_{15}}$ & 0.02 & 0.02 & 4.4 & 0.0125 \\
\hline & & $T_{\text {soil }_{05}}$ & - & - & - & 0.80 & $T_{\text {soil }_{05}}$ & 0.02 & 0.04 & 3.2 & 0.0049 \\
\hline \multirow{12}{*}{$\begin{array}{l}\text { Leaf } \\
\text { photosynthesis }\end{array}$} & \multirow{3}{*}{ A. gerardii } & $\Theta_{15}$ & 0.011 & 57.9 & 0.52 & $<0.0001$ & $\Theta_{15}$ & 0.52 & 0.52 & 103.8 & $<0.0001$ \\
\hline & & $\mathrm{CV}_{\Theta_{15}}$ & - & - & - & 0.11 & $\mathrm{CV}_{\Theta_{15}}$ & 0.08 & 0.61 & 20.4 & $<0.0001$ \\
\hline & & $T_{\text {soil }_{05}}$ & 28.75 & 0.66 & 0.04 & 0.04 & $T_{\text {soil }_{05}}$ & 0.02 & 0.63 & 5.8 & 0.018 \\
\hline & \multirow{3}{*}{ S. nutans } & $\Theta_{15}$ & 3.05 & 36.74 & 0.19 & 0.005 & $\Theta_{15}$ & 0.19 & 0.19 & 13.6 & 0.003 \\
\hline & & $\mathrm{CV}_{\Theta_{15}}$ & - & - & - & 0.38 & $\mathrm{CV}_{\Theta_{15}}$ & - & - & - & - \\
\hline & & $T_{\text {soil }_{05}}$ & -14.48 & 0.95 & 0.12 & 0.007 & $T_{\text {soil }_{05}}$ & 0.08 & 0.27 & 6.1 & 0.019 \\
\hline & \multirow{3}{*}{$\begin{array}{l}\text { Grasses } \\
\text { combined }\end{array}$} & $\Theta_{15}$ & 0.40 & 54.34 & 0.44 & $<0.0001$ & $\Theta_{15}$ & 0.44 & 0.44 & 122.9 & $<0.0001$ \\
\hline & & $\mathrm{CV}_{\Theta_{15}}$ & 7.19 & 0.10 & 0.02 & 0.03 & $\mathrm{CV}_{\Theta_{15}}$ & 0.08 & 0.52 & 26.8 & $<0.0001$ \\
\hline & & $T_{\text {soil }_{05}}$ & - & - & - & 0.46 & $T_{\text {soil }} 05$ & 0.01 & 0.54 & 3.5 & $<0.0001$ \\
\hline & \multirow{3}{*}{ S. canadensis } & $\Theta_{15}$ & 7.04 & 19.8 & 0.19 & 0.004 & $\Theta_{15}$ & 0.22 & 0.22 & 9.4 & 0.009 \\
\hline & & $\mathrm{CV}_{\Theta_{15}}$ & - & - & - & 0.14 & $\mathrm{CV}_{\Theta_{15}}$ & 0.10 & 0.32 & 5.0 & 0.0322 \\
\hline & & $T_{\text {soil }_{05}}$ & - & - & - & 0.22 & $T_{\text {soil }_{05}}$ & - & - & - & - \\
\hline \multirow{3}{*}{ Soil $\mathrm{CO}_{2}$ flux } & & $\Theta_{15}$ & 5.19 & 12.04 & 0.18 & $<0.0001$ & $\mathrm{CV}_{\Theta_{15}}$ & 0.27 & 0.27 & 60.3 & $<0.0001$ \\
\hline & & $\mathrm{CV}_{\Theta_{15}}$ & 11.65 & -0.09 & 0.28 & $<0.0001$ & $T_{\text {soil }_{05}}$ & 0.06 & 0.33 & 15.5 & 0.0001 \\
\hline & & $T_{\text {soil }_{05}}$ & - & - & - & 0.90 & $\Theta_{15}$ & 0.11 & 0.44 & 31.2 & $<0.0001$ \\
\hline
\end{tabular}

variation in total ANPP, forb ANPP, $J_{\mathrm{CO}_{2}}$, and $S$. nutans $A_{\mathrm{CO}_{2}}(0.0001<p<0.02)$, and not entering models for grass ANPP or $A_{\mathrm{CO}_{2}}$ of A. gerardii or $S$. canadensis.

\section{Discussion}

Results from ten years of experimental rainfall manipulation and five years of warming treatments encompassing a wide range of natural climatic variability show that interannual climate variation, increased intra-annual (growing season) rainfall variability, and warming all affected key ecosystem processes. There was more interannual variation in ecosystem function than there was from intra-annual rainfall variability and warming. However the relatively smaller effects of intra-annual rainfall variability and warming still caused significant effects on some processes.

\subsection{Interannual variability caused greater effects than increased intra-annual rainfall variability on most ecosystem processes}

Our analyses demonstrated that large (nearly 2-fold) interannual variation in total (May-September) rainfall resulted in $\sim 40 \%$ interannual variation in growing season mean soil moisture $\left(\Theta_{15}\right)$. The magnitude of interannual rainfall variability was greater than that of interannual mean soil moisture variability because of the limited capacity for soil to store rainfall (Brady and Weil, 2002; Rodriguez-Iturbe and Porporato, 2004). Nonetheless, variation in $\Theta_{15}$ was associated with 50 to $300 \%$ variation in rates of key ecosystem processes. High interannual variation in total ANPP resulted from high variation in grass ANPP (Fig. 5a, b), which is consistent with previous studies (Briggs and Knapp, 1995; Knapp et al., 2001). In contrast, forb ANPP was relatively constant among years (Fig. 5d), as reported in previous studies (Knapp et al., 2001). Interannual variation in flowering of the codominant grasses was also high, but qualitatively different from that of total ANPP. Flowering was high only during the two years with the highest $\Theta_{15}$ (1999 and 2004), and was consistently low in other years, suggesting there is a threshold total rainfall requirement for flowering in these grasses. Craine et al. (2010) also found a threshold requirement for grass flowering in this grassland. A rainfall regime with more frequent drought years could result in fewer flowering events, potentially lowering future inputs to the seed bank from these grasses. 


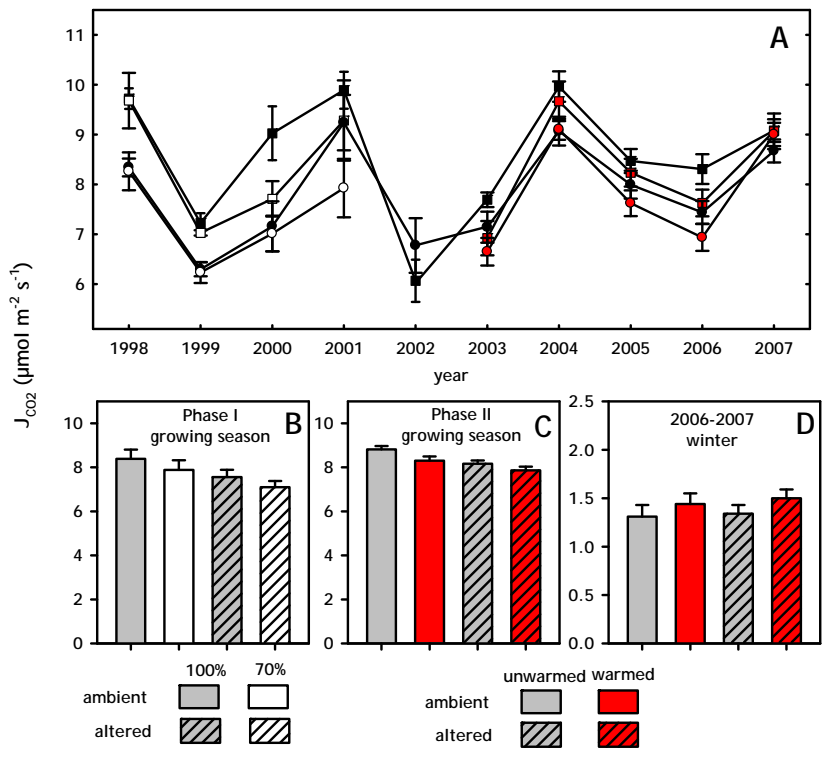

Fig. 7. Soil $\mathrm{CO}_{2}$ efflux $\left(J_{\mathrm{CO}_{2}}\right)$ by rainfall and warming treatments. (A) Mean growing season $J_{\mathrm{CO}_{2}}$ by year, symbols as in Fig. 1. Growing season mean $J_{\mathrm{CO}_{2}}$ during (B) Phase I and (C) Phase II. (D) Winter $J_{\mathrm{CO}_{2}}$ by rainfall pattern and warming during 2006-2007. Note that scaling for (D) differs from that for (B-C). Error bars denote $1 \mathrm{SE}$ of the mean.

Interannual variability in $A_{\mathrm{CO}_{2}}$ of the grasses was of comparable magnitude to that of total ANPP. We expected interannual variability to have a smaller effect on $A_{\mathrm{CO}_{2}}$ relative to that of intra-annual rainfall variability, because $A_{\mathrm{CO}_{2}}$ in these grasses decreases strongly with soil moisture depletion, and recovery is often slow when soil moisture is restored, especially after extended drought (Knapp, 1985; Heckathorn et al., 1997). Leaf level photosynthesis has been associated with long-term plant success in this grassland (McAllister et al., 1998), and the ability to track soil moisture variability is crucial to the success of the grasses (Swemmer et al., 2006; Nippert et al., 2006a). The finding that $A_{\mathrm{CO}_{2}}$ was strongly correlated with $\Theta_{15}$ (Table 1) suggests that on average, $A_{\mathrm{CO}_{2}}$ was strongly coupled to interannual climate variation and associated interannual differences in soil water supply.

High responsiveness in grass $A_{\mathrm{CO}_{2}}$ to interannual variation was consistent with grass growth responses. For example, grass ANPP and $A_{\mathrm{CO}_{2}}$ was more highly correlated with $\Theta_{15}$ than was forb ANPP and $A_{\mathrm{CO}_{2}}$ (Table 1). $\mathrm{C}_{4}$ grasses such as $A$. gerardii and $S$. nutans typically have higher photosynthetic rates and experience greater variation in plant water status than forbs (Knapp, 1984; Turner et al., 1995; McAllister et al., 1998; Nippert et al., 2006a). Stable isotope studies of soil water use by $\mathrm{C}_{4}$ grasses at the Konza site shows that they rely on surface soil water regardless of landscape location, soil water availability, or time of year, while forbs increase their dependence on deeper soil moisture as surface soils dry (Nippert and Knapp, 2007a, b). Such differential access to soil moisture among species and functional groups

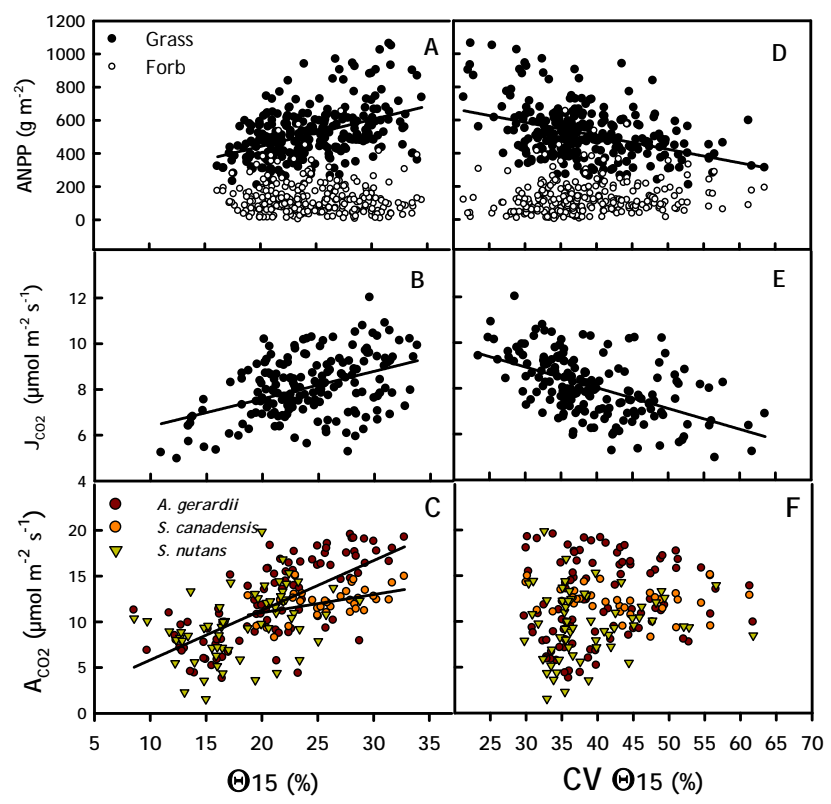

Fig. 8. Correlations of grass and forb aboveground net primary productivity (ANPP), growing season means of leaf photosynthesis $\left(A_{\mathrm{CO}_{2}}\right)$ and soil $\mathrm{CO}_{2}$ flux $\left(J_{\mathrm{CO}_{2}}\right)$ with $0-15 \mathrm{~cm}$ volumetric soil water content $\left(\Theta_{15}\right)$ and the coefficient of variation of $\Theta_{15}\left(\mathrm{CV}_{\Theta_{15}}\right)$. Regression statistics are shown in Table 1.

could provide a mechanism for increased temporal variability in community structure under more variable rainfall regimes.

\subsection{Increased intra-annual rainfall variability reduced rates of ecosystem processes, other things being equal}

The altered rainfall timing treatment markedly changed the probability distributions of rainfall inputs (Fig. 1b), increasing the variability in rainfall by creating longer dry periods and larger rainfall events. This translated directly to increased soil moisture variability and reduced mean $\Theta_{15}$ in some or all years, caused by the prolonged periods of low soil moisture during the longer dry periods. This confirms and extends our previous findings of the effects of increased rainfall variability on soil moisture dynamics in this grassland (Knapp et al., 2002; Fay et al., 2003a, 2008). Since total rainfall inputs were unchanged, increased rainfall variability reduced the effective storage of rainfall in the upper part of the soil profile.

We found that soil moisture variability was a decreasing function of mean soil moisture (Fig. 2). In contrast, we previously reported that soil moisture variability was independent of mean soil moisture in our experiment (Knapp et al., 2002; Fay et al., 2003a). However, the current finding is based on a longer data set, emphasizing the need for long-term manipulations that capture enough natural rainfall variability to correctly show the relationship of interannual variation in soil moisture (Davidowitz, 2002). 
Increased intra-annual rainfall variability significantly affected most ecosystem processes when compared to an equal amount of rainfall at ambient variability. However, the effects of interannual variation for soil moisture and most ecosystem processes were considerably larger than the effect of increased intra-annual variability (Fig. 9a inset) and most ecosystem processes. Increased rainfall variability reduced plant growth and leaf and soil $\mathrm{CO}_{2}$ fluxes only 8-17\% despite the large increase in the amplitude of soil moisture variability $\left(\Delta \Theta_{15}\right)$. This confirms and extends our earlier findings (Knapp et al., 2002). The reduction in rates of ecosystem processes with altered rainfall timing suggest that increased rainfall variability increased water limitation in this grassland. The result of increased water limitation may be a grassland that is more sensitive to interannual climate variation (Huxman et al., 2004).

The magnitude of interannual variation in $J_{\mathrm{CO}_{2}}(\sim 46 \%)$ was less than interannual variation in leaf carbon assimilation or total ANPP. A similar magnitude of interannual variation in $J_{\mathrm{CO}_{2}}$ was reported in a semiarid grassland by Liu et al. (2009) and in an annual grassland by Chou et al. (2009). However, in the multiple regression analysis, $\mathrm{CV}_{\Theta_{15}}$ explained more variation in $J_{\mathrm{CO}_{2}}$ than did $\Theta_{15}$, suggesting that $J_{\mathrm{CO}_{2}}$ was actually more strongly associated with intra-annual rainfall variability. This result could be explained if soil moisture variability disproportionately affected belowground processes such as allocation of current photosynthate to roots, root biomass, litter decomposition, or microbial biomass or substrate availability (Luo and Zhou, 2006), resulting in greater reductions in overall belowground metabolic activity compared to those from mean soil moisture.

\subsection{Warming effects occur at different times of year than intra-annual rainfall effects}

The warming treatment raised soil temperature, especially during spring, fall, and winter. The most apparent effects of warming were found in canopy greenness, soil respiration, and forb ANPP. The marked increase in spring canopy greenness indicates that warming advanced ecosystem phenology. This result is consistent with findings from larger spatial scales (Badeck et al., 2004). Warming effects on canopy greenness diminished and were replaced by altered rainfall effects from late spring through the remainder of the growing season. This result suggests a transition from temperature control of early spring canopy greenness to control by rainfall variability. The lack of late season response to warming contrasts with some studies, where warming led to earlier senescence in annual grassland (Zavaleta et al., 2003) and increased fall green aboveground biomass (Wan et al., 2005). In this system, the lack of late warming response could be explained by several mechanisms, such as acclimation to warming over the growing season, possibly combined with inadequate late season soil moisture (Gielen et al., 2005).
The warming treatment reduced mean growing season $J_{\mathrm{CO}_{2}}$ by about $5 \%$. Liu et al. (2009) also found reduced $J_{\mathrm{CO}_{2}}$ with experimental warming in semiarid grassland, while warming increased annual $J_{\mathrm{CO}_{2}}$ in Oklahoma tallgrass prairie (Zhou et al., 2006). An increase in soil respiration of about $20 \%$ with warming was typical across grassland, forest, and desert ecosystems (Rustad et al., 2001). $J_{\mathrm{CO}_{2}}$ is an increasing function of soil temperature and a quadratic function of soil moisture in our experiment (Harper et al., 2005). Our finding of lower $J_{\mathrm{CO}_{2}}$ despite warmed soil may mean that lower soil moisture offset the stimulatory effect of warming. The quadratic response of $J_{\mathrm{CO}_{2}}$ to soil moisture may explain why warming may cause lower $J_{\mathrm{CO}_{2}}$ with reduced soil moisture in some cases (Liu et al., 2009) or higher $J_{\mathrm{CO}_{2}}$ with reduced soil moisture in others (Zhou et al., 2006).

In contrast, warming caused a marked increase in $J_{\mathrm{CO}_{2}}$ during winter. This suggests that winter soil respiration was primarily limited by soil temperature. Similarly, Almagro et al. (2009) found that soil respiration increased with soil temperature during moist, cool conditions. The increase in winter $\mathrm{CO}_{2}$ efflux, while small in absolute terms, would still affect total annual soil $\mathrm{CO}_{2}$ efflux. As a result, annual responses in soil respiration to global changes cannot be inferred from short-term or growing season measurements, but the entire year must be accounted for.

Reduced forb ANPP was the most consistent effect of the warming treatment on plant growth. Specific mechanisms for this response cannot be deduced from the present dataset, but may include altered aboveground or belowground competitive interactions with grasses, based on, for example, differences in growth rates, allocation patterns or photosynthetic efficiencies. Because forbs contribute much of the plant diversity in these grasslands, warming may be a stronger driver of biodiversity change over time than increased rainfall variability. However, reduced forb ANPP only translated into reduced total ANPP in two out of five years. This overall lack of strong warming responses in ANPP indicated that following spring green up, rainfall variability was the main driver of biomass accumulation. Warming did not affect biomass production in annual grassland (Dukes et al., 2005), forb biomass in alpine meadow (de Valpine and Harte, 2001), or grass and forb biomass in semiarid Mongolian steppe (Xia et al., 2009). However warming reduced aboveground biomass in experimental grassland assemblages grown in a cool temperate climate, due to lower soil moisture (De Boeck et al., 2008). The weak effect of the warming treatment on total ANPP was consistent with the MR finding that $T_{\text {soil } 05}$ explained little variation in these processes. Wan et al. (2005) and Klein et al. (2005) reported similar results in grasslands. 

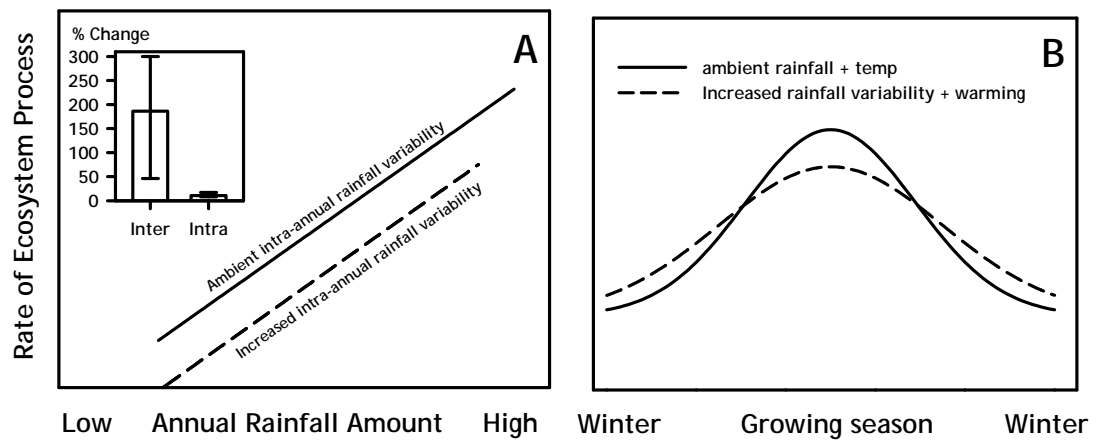

Fig. 9. Conceptual model of the coupled effects of (A) Annual rainfall amount and increased intra-annual rainfall variability, showing here the simplest case of a linear relationship of ecosystem function with rainfall amount for this ecosystem, and (B) increased intra-annual rainfall variability and warming on ecosystem processes. The inset shows the mean and range of the \% change in four primary ecosystem processes (aboveground net primary productivity, midseason aboveground biomass, $A_{\mathrm{CO}_{2}}$ of $A$. gerardii, and $J_{\mathrm{CO}_{2}}$ ) to interannual and intra-annual (increased rainfall variability) effects.

\subsection{A conceptual model of the coupling of rainfall variability and warming}

The findings from the first ten years of this experiment suggest that interannual climate variation, increased growing season rainfall variability, and warming can be hypothesized to exert effects on this grassland ecosystem in the following ways.

1. Interannual climate variation, mainly in growing season rainfall total, drives interannual variation in average soil moisture and rates of key ecosystem processes (Fig. 9a).

2. Increased intra-annual (growing season) rainfall variability reduces rates of most ecosystem processes compared to ambient rainfall patterns with the same total amount of rainfall. This reduction in ecosystem function (sensu Hui et al., 2003) is an indicator of lower ecosystem rainfall use efficiency resulting from greater temporal variability in growing season soil moisture.

3. Within a growing season (Fig. 9b), warming likely stimulates ecosystem processes during cooler parts of the growing season (e.g. spring canopy development, winter $\mathrm{CO}_{2}$ efflux), but during the middle, warmer and water-limited portion of the growing season, increased rainfall variability and warming effects where they occur likely reduce rates of ecosystem processes. This sequential difference in the effects of warming and increased intra-annual rainfall variability changes the seasonal dynamics of ecosystem processes, compared to ambient temperature and variability.

This framework reveals several gaps in our understanding of the effects of rainfall and temperature variability on this grassland, indicating important areas for further research.

1. For the ranges of rainfall amounts and ecosystem responses in this study, we suggest a linear relationship between rainfall amount and average rates of ecosystem processes (Fig. 9a). However over a larger range of rainfall, asymptotic or threshold responses could occur.

2. In the simplest, linear case, increased intra-annual rainfall variability will decrease ecosystem processes equally at all rainfall amounts (Fig. 9a). However if ecosystem responses to rainfall amount prove to be nonlinear, we would expect greater effects of increased rainfall variability at intermediate rainfall amounts. Variability effects will decrease at high rainfall amounts because of less frequent soil moisture deficit, and at low rainfall amounts because of lower overall soil moisture.

3. The interactive effects of rainfall amount and intraannual variability (Fig. 9a), and the transitions between effects of rainfall variability and warming (Fig. 9b) will likely differ among processes.

\section{Conclusions}

For several major ecosystem processes in this grassland interannual variability was the strongest driver, followed by intra-annual rainfall variability and warming. The nature of the relationship between intra-annual rainfall variability and warming has important implications for understanding the effects of climate change on this grassland, and its ability to sustainably provide food and fiber while supporting biological diversity and other ecosystem goods and services. Future research should seek explanation for how the interactive effects of these drivers may change in wetter or drier ecosystems (Knapp et al., 2008; Heisler-White et al., 2009), and examine daily to weekly variability, which strongly affects soil moisture and $\mathrm{CO}_{2}$ fluxes (Fay et al., 2003b; Ogle and Reynolds, 2004; Harper et al., 2005). 


\section{Appendix A}

Table A1. Analysis of variance $F$ statistics for rainfall and soil moisture variation responses to pattern, quantity, and warming treatments in RaMPs.

\begin{tabular}{|c|c|c|c|c|c|c|c|c|c|}
\hline & \multirow[t]{2}{*}{ Rainfall CV } & \multirow[t]{2}{*}{$\Theta_{15}$} & \multirow[t]{2}{*}{$\Delta \Theta_{15}$} & \multirow[t]{2}{*}{$\mathrm{CV}_{\Theta_{15}}$} & \multirow[t]{2}{*}{$T_{\text {soil }_{05}}$} & \multirow[t]{2}{*}{ Soil $\mathrm{CO}_{2}$ flux } & \multicolumn{3}{|c|}{ Leaf photosynthesis } \\
\hline & & & & & & & A. gerardii & S. canadensis & S. nutans \\
\hline \multicolumn{10}{|l|}{ 1998-2007 } \\
\hline Pattern & $2907.8^{\mathrm{c}}$ & $15.5^{\mathrm{b}}$ & $819.0^{\mathrm{c}}$ & $9.1^{\mathrm{a}}$ & $11.1^{\mathrm{a}}$ & $25.2^{\mathrm{c}}$ & $4.1^{\mathrm{a}}$ & - & 0.1 \\
\hline Year & $87.0^{\mathrm{c}}$ & $44.9^{\mathrm{c}}$ & $127.2^{\mathrm{c}}$ & $69.3^{\mathrm{c}}$ & $352.2^{\mathrm{c}}$ & $21.8^{\mathrm{c}}$ & $95.0^{\mathrm{c}}$ & - & $31.4^{\mathrm{c}}$ \\
\hline Year * Pattern & $52.0^{\mathrm{c}}$ & $11.2^{\mathrm{c}}$ & $26.3^{\mathrm{c}}$ & $7.6^{\mathrm{c}}$ & 1.2 & 1.4 & $4.2^{\mathrm{b}}$ & - & $5.9^{\mathrm{b}}$ \\
\hline \multicolumn{10}{|l|}{ 1998-2001 } \\
\hline Pattern & $26809.0^{\mathrm{c}}$ & $60.0^{\mathrm{c}}$ & $95.5^{\mathrm{c}}$ & $40.5^{\mathrm{c}}$ & - & $30.4^{\mathrm{c}}$ & $7.4^{\mathrm{a}}$ & 0.8 & - \\
\hline Quantity & $8.2^{\mathrm{a}}$ & $14.2^{\mathrm{a}}$ & 0.1 & 5.2 & - & $5.0^{\mathrm{a}}$ & 0.0 & $8.2^{\mathrm{a}}$ & - \\
\hline Pattern * Quantity & $24.6^{\mathrm{c}}$ & $1.9^{\mathrm{c}}$ & 1.2 & 1.8 & - & 0.1 & 0.9 & 2.0 & - \\
\hline Year & $234.5^{\mathrm{c}}$ & $65.4^{\mathrm{c}}$ & $8.3^{\mathrm{b}}$ & $11.2^{\mathrm{c}}$ & - & $31.6^{\mathrm{c}}$ & $32.5^{\mathrm{c}}$ & 3.3 & - \\
\hline Year * Pattern & $88.7^{\mathrm{c}}$ & $8.7^{\mathrm{b}}$ & 1.6 & $7.5^{\mathrm{b}}$ & - & 0.2 & $8.1^{\mathrm{b}}$ & 1.0 & - \\
\hline Year* Quantity & $126.8^{\mathrm{c}}$ & 2.6 & 1.4 & 1.6 & - & 1.0 & 0.8 & 1.4 & - \\
\hline Year * Pattern * Quantity & $83.8^{\mathrm{c}}$ & 2.1 & 2.0 & 1.1 & - & 0.8 & 2.4 & 1.1 & - \\
\hline \multicolumn{10}{|l|}{ 2003-2007 } \\
\hline Pattern & $1542.0^{\mathrm{c}}$ & $13.0^{\mathrm{b}}$ & $787.4^{\mathrm{c}}$ & $20.1^{\mathrm{b}}$ & $8.0^{\mathrm{a}}$ & 3.8 & 0.7 & - & 1.0 \\
\hline Warming & - & 2.9 & 0.3 & 0.0 & $219.8^{\mathrm{c}}$ & $4.4^{\mathrm{a}}$ & 3.3 & - & 1.6 \\
\hline Pattern * Warming & - & 0.3 & 0.2 & 1.1 & 0.0 & 0.4 & 0.1 & - & 0.3 \\
\hline Year & $52.4^{\mathrm{c}}$ & $115.0^{\mathrm{c}}$ & $53.1^{\mathrm{c}}$ & $98.9^{\mathrm{c}}$ & $731.5^{\mathrm{c}}$ & $62.6^{\mathrm{c}}$ & $45.0^{\mathrm{c}}$ & - & $50.9^{\mathrm{c}}$ \\
\hline Year * Pattern & $97.9^{\mathrm{c}}$ & $24.6^{\mathrm{c}}$ & $39.5^{\mathrm{c}}$ & $5.6^{\mathrm{c}}$ & $6.1^{\mathrm{c}}$ & 1.0 & 0.4 & - & 1.4 \\
\hline Year * Warming & - & 2.0 & 0.7 & $3.1^{\mathrm{a}}$ & $15.5^{\mathrm{c}}$ & 2.0 & 0.0 & - & 0.1 \\
\hline Year * Pattern * Warming & - & 0.9 & 1.2 & 0.4 & 2.5 & 0.2 & 0.3 & - & 0.2 \\
\hline
\end{tabular}

${ }^{\mathrm{a}} p<0.05 ;{ }^{\mathrm{b}} p<0.01 ;{ }^{\mathrm{c}} p<0.001$

Table A2. Analysis of variance $F$ statistics for vegetation responses to pattern, quantity, and warming treatments in RaMPs.

\begin{tabular}{|c|c|c|c|c|c|c|c|c|c|}
\hline & \multicolumn{3}{|c|}{ Canopy greenness } & \multirow{2}{*}{$\begin{array}{c}\text { Canopy } \\
\text { light penetration } \\
x_{0}\end{array}$} & \multicolumn{3}{|c|}{$\begin{array}{c}\text { Aboveground net } \\
\text { primary productivity }\end{array}$} & \multicolumn{2}{|c|}{ Plant reproduction } \\
\hline & Weeks $15-20$ & Weeks 20-22 & Weeks 35-43 & & Total & Grass & Forb & A. gerardii & S. nutans \\
\hline \multicolumn{10}{|l|}{ 1998-2007 } \\
\hline Pattern & - & - & - & $6.0^{\mathrm{a}}$ & $8.9^{\mathrm{b}}$ & 2.1 & 0.8 & 0.3 & $14.3^{b}$ \\
\hline Year & - & - & - & $65.6^{\mathrm{c}}$ & $28.3^{\mathrm{c}}$ & $26.2^{\mathrm{c}}$ & $10.5^{\mathrm{c}}$ & $45.8^{\mathrm{c}}$ & $76.5^{\mathrm{c}}$ \\
\hline Year * Pattern & - & - & - & $2.2^{\mathrm{a}}$ & 1.4 & 0.9 & 0.4 & 0.9 & $3.4^{\mathrm{b}}$ \\
\hline \multicolumn{10}{|l|}{ 1998-2001 } \\
\hline Pattern & - & - & - & $5.7^{\mathrm{a}}$ & $12.2^{\mathrm{b}}$ & 3.8 & 0.4 & 0.1 & $13.6^{\mathrm{b}}$ \\
\hline Quantity & - & - & - & 2.0 & $5.9^{\mathrm{a}}$ & 4.1 & 0.1 & 0.2 & 0.1 \\
\hline Pattern * Quantity & - & - & - & 0.1 & 0.2 & 0.0 & 0.2 & 1.0 & 0.0 \\
\hline Year & - & - & - & $11.2^{\mathrm{c}}$ & $12.4^{\mathrm{c}}$ & $9.1^{\mathrm{c}}$ & $14.8^{\mathrm{c}}$ & 2.0 & $40.8^{\mathrm{c}}$ \\
\hline Year * Pattern & - & - & - & 2.5 & 0.4 & 0.3 & 0.2 & 0.2 & 1.5 \\
\hline Year* Quantity & - & - & - & 0.0 & 0.4 & 0.4 & 1.2 & 0.6 & 3.8 \\
\hline Year* Pattern * Quantity & - & - & - & 0.0 & 0.3 & 1.6 & 0.8 & 1.6 & 1.7 \\
\hline \multicolumn{10}{|l|}{$2003-2007$} \\
\hline Pattern & 1.0 & $10.8^{\mathrm{c}}$ & 2.4 & 3.5 & 2.7 & 0.7 & 0.1 & 0.6 & $5.1^{\mathrm{a}}$ \\
\hline Warming & $161.5^{\mathrm{c}}$ & $17.3^{\mathrm{c}}$ & 0.7 & 0.0 & $4.7^{\mathrm{a}}$ & 0.0 & $4.8^{\mathrm{a}}$ & 2.1 & 1.3 \\
\hline Pattern * Warming & 3.5 & 0.3 & 0.0 & 0.3 & 0.1 & 0.1 & 0.7 & 1.0 & 0.5 \\
\hline Year & $240.6^{\mathrm{c}}$ & $50.5^{\mathrm{c}}$ & $69.3^{\mathrm{c}}$ & $80.4^{\mathrm{c}}$ & $49.8^{\mathrm{c}}$ & $51.6^{\mathrm{c}}$ & $18.4^{\mathrm{c}}$ & $209.4^{\mathrm{c}}$ & $275.1^{\mathrm{c}}$ \\
\hline Year * Pattern & 0.3 & 0.4 & 1.7 & $8.1^{\mathrm{c}}$ & 1.9 & 1.4 & 0.8 & $2.9^{\mathrm{a}}$ & $9.8^{\mathrm{c}}$ \\
\hline Year * Warming & $22.8^{\mathrm{c}}$ & 0.5 & 1.4 & $5.9^{\mathrm{c}}$ & 2.0 & $3.1^{\mathrm{a}}$ & 0.2 & 0.4 & 0.8 \\
\hline Year * Pattern * Warming & 1.8 & 0.1 & 0.0 & 0.8 & 0.9 & 1.6 & 0.4 & 1.0 & 2.4 \\
\hline
\end{tabular}

${ }^{\mathrm{a}} p<0.05 ;{ }^{\mathrm{b}} p<0.01 ;{ }^{\mathrm{c}} p<0.001$ 
Acknowledgements. We thank Doug Goodin for providing the canopy imager; Meghan Dinkins, Chris Harper, Chris Hein, Patrick O'Neal, Rose Phillips, Jeff Taylor and numerous undergraduate and graduate students for their contributions to all aspects of this research. Tom Van Slyke and Jim Larkins graciously provide ongoing logistic and technical support. Wayne Polley and Marjan Jongen provided insightful feedback on the manuscript. We acknowledge funding from USDA-NRI, DOE-NIGEC/NICCR, and NSF.

\section{Edited by: D. Zona}

\section{References}

Almagro, M., López, J., Querejeta, J. I., and Martinez-Mena, M.: Temperature dependence of soil $\mathrm{CO}_{2}$ efflux is strongly modulated by seasonal patterns of moisture availability in a Mediterranean ecosystem, Soil Biol. Biochem., 41, 594-605, 2009.

An, Y., Wan, S., Zhou, X., Subedar, A. A., Wallace, L. L., and Luo, Y.: Plant nitrogen concentration, use efficiency, and contents in a tallgrass prairie ecosystem under experimental warming, Glob. Change Biol., 11, 1733-1744, 2005.

Badeck, F. W., Bondeau, A., Bottcher, K., Doktor, D., Lucht, W., Schaber, J., and Sitch, S.: Responses of spring phenology to climate change, New Phytol., 162, 295-309, 2004.

Bonan, G. B.: Ecological Climatology, Cambridge University Press, Cambridge, UK, 678 pp., 2002.

Brady, N. C. and Weil, R. R.: The nature and properties of soils, 13th, Prentice Hall, Upper Saddle River, NJ, 960 pp., 2002.

Briggs, J. M. and Knapp, A. K.: Interannual variability in primary production in tallgrass prairie: climate, soil moisture, topographic position, and fire as determinants of aboveground biomass, Am. J. Bot., 82, 1027-1030, 1995.

CCSP: Thresholds of Climate Change in Ecosystems., U.S. Geological Survey, Reston, VA, 156 pp., 2010.

Chou, W. W., Silver, W. L., Jackson, R. D., Thompson, A. W., and Allen-Diaz, B.: The sensitivity of annual grassland carbon cycling to the quantity and timing of rainfall, Glob. Change Biol., 14, 1382-1394, 2009.

Cleland, E. E., Chiariello, N. R., Loarie, S. R., Mooney, H. A., and Field, C. B.: Diverse responses of phenology to global changes in a grassland ecosystem, P. Natl. Acad. Sci., 103, 13740-13744, 2006.

Craine, J. M., Towne, E. G., and Nippert, J. B.: Climate controls on grass culm production over a quarter century in a tallgrass prairie, Ecology, 91, 2132-2140, 2010.

Davidowitz, G.: Does precipitation variability increase from mesic to xeric biomes?, Global Ecol. Biogeogr., 11, 143-154, 2002.

De Boeck, H. J., Lemmens, C. M. H. M., Zavalloni, C., Gielen, B., Malchair, S., Carnol, M., Merckx, R., Van den Berge, J., Ceulemans, R., and Nijs, I.: Biomass production in experimental grasslands of different species richness during three years of climate warming, Biogeosciences, 5, 585-594, doi:10.5194/bg5-585-2008, 2008.

de Valpine, P. and Harte, J.: Plant responses to experimental wamring in a montane meadow, Ecology, 82, 637-648, 2001.

Denman, K. L., Brasseur, G., Chidthaisong, A., Ciais, P., Cox, P. M., Dinickinson, R. E., Hauglustaine, D., Heinze, C., Holland, E., Jacob, D., Lohmann, U., Ramarchandran, S., daSilva-
Dias, P. L., Wofsy, S. C., and Zhang, X.: Couplings between changes in the climate system and biogeochemistry, in: Climate Change 2007: The Physical Science Basis. Contribution of Working Group I to the Fourth Assessment Report of the Intergovernmental Panel on Climate Change, edited by: Solomon, S., Quin, D., Manning, M., Chen, Z., Marquis, M., Avery, K. B., Tignor, M., and Miller, H. L., Cambridge University Press, Cambridge, United Kingdom and New York, NY, 500-587, 2007.

Dukes, J. S., Chiariello, N. R., Cleland, E. E., Moore, L. A., Shaw, M. R., Thayer, S., Tobeck, T., Mooney, H. A., and Field, C. B.: Responses of grassland production to single and multiple global environmental changes, PLoS Biology, 3, 1829-1837, 2005.

Fay, P. A., Carlisle, J. D., Knapp, A. K., Blair, J. M., and Collins, S. L.: Altering rainfall timing and quantity in a mesic grassland ecosystem: Design and performance of rainfall manipulation shelters, Ecosystems, 3, 308-319, 2000.

Fay, P. A., Carlisle, J. D., Danner, B. N., Lett, M. S., McCarron, J. K., Stewart, C., Knapp, A. K., Blair, J. M., and Collins, S. L.: Altered rainfall patterns, gas exchange, and growth in grasses and forbs, Int. J. Plant Sci., 163, 549-557, 2002.

Fay, P. A., Carlisle, J. D., Knapp, A. K., Blair, J. M., and Collins, S. L.: Productivity responses to altered rainfall patterns in a $\mathrm{C}_{4}-$ dominated grassland, Oecologia, 137, 245-251, $2003 \mathrm{a}$.

Fay, P. A., Knapp, A. K., Blair, J. M., Carlisle, J. D., Danner, B. T., and McCarron, J. K.: Rainfall timing, soil moisture dynamics, and plant responses in a mesic tallgrass prairie ecosystem, in: Precipitation Impacts on Terrestrial Ecosystems, edited by: Weltzin, J. F. and McPherson G. R., University of Arizona Press, 147-163, 2003b.

Fay, P. A., Kaufman, D. M., Nippert, J. B., Carlisle, J. D., and Harper, C. W.: Changes in grassland ecosystem function due to extreme rainfall events: implications for responses to climate change, Glob. Change Biol., 14, 1600-1608, 2008.

Gielen, B., De Boeck, H. J., Lemmens, C. M. H. M., Valcke, R., Nijs, I., and Ceulemans, R.: Grassland species will not necessarily benefit from future elevated air temperatures: a chlorophyll fluorescence approach to study autumn physiology, Phys. Plant., 125, 52-63, 2005.

Goodin, D. G., Fay, P. A., and McHugh, M. M.: Climate variability at a tallgrass prairie site at multiple time scales: Konza Prairie Biological Station, in: Climate variability and ecosystem response at long-term ecological research (LTER) sites, edited by: Greenland, D., Fountain, A., Goodin, D. G., Juday, G., Lyons, B., and Smith, R., Oxford University Press, New York, 411-424, 2002.

Groisman, P. Y. and Knight, R. W.: Prolonged dry episodes over the conterminous United States: New tendencies emerging during the last 40 years, J. Climate, 21, 1850-1862, 2008.

Groisman, P. Y., Knight, R. W., Easterling, D. R., Karl, T. R., Hegerl, G. C., and Razuvaev, V. N.: Trends in Intense Precipitation in the Climate Record, J. Climate, 18, 1326-1350, 2005.

Harper, C. W., Blair, J. M., Fay, P. A., Knapp, A. K., and Carlisle, J. D.: Increased rainfall variability and reduced rainfall amount decreases soil $\mathrm{CO}_{2}$ flux in a grassland ecosystem, Glob. Change Biol., 11, 322-334, 2005.

Heckathorn, S. A., DeLucia, E. H., and Zielinski, R. E.: The contribution of drought-related decreases in foliar nitrogen concentration to decreases in photosynthetic capacity during and after drought in prairie grasses, Phys. Plant., 101, 173-182, 1997.

Heisler-White, J. L., Knapp, A. K., and Kelly, E. F.: Increasing pre- 
cipitation event size increases aboveground net primary productivity in a semi-arid grassland, Oecologia, 158, 129-140, 2009.

Hoekstra, J. M., Boucher, T. M., Ricketts, T. H., and Roberts, C.: Confronting a biome crisis: global disparities of habitat loss and protection, Ecol. Lett., 8, 23-29, 2005.

Hui, D., Luo, Y., and Katul, G.: Partitioning interannual variability in net ecosystem exchange between climatic variability and functional change, Tree Physiol., 23, 433-442, 2003.

Huxman, T. E., Smith, M. D., Fay, P. A., Knapp, A. K., Shaw, M. R., Loik, M. E., Smith, S. D., Tissue, D. T., Zak, J. C., Weltzin, J. F., Pockman, W. T., Sala, O. E., Haddad, B. M., Harte, J., Koch, G. W., Schwinning, S., Small, E. E., and Williams, D. G.: Convergence across biomes to a common rain-use efficiency, Nature, 429, 651-654, 2004.

Karl, T. R., Melillo, J. M., and Peterson, T. C.: Global Climate Change Impacts in the United States, Cambridge University Press, New York, 2009.

Klein, J. A., Harte, J., and Zhao, X. Q.: Dynamic and complex microclimate responses to warming and grazing manipulations, Glob. Change Biol., 11, 1440-1451, 2005.

Knapp, A. K.: Water relations and growth of three grasses during wet and drought years in a tallgrass prairie, Oecologia, 65, 3543, 1984.

Knapp, A. K.: Effect of fire and drought on the ecophysiology of Andropogon gerardii and Panicum virgatum in a tallgrass prairie, Ecology, 66, 1309-1320, 1985.

Knapp, A. K., Briggs, J. M., Hartnett, D. C., and Collins, S. L.: Grassland dynamics: long-term ecological research in tallgrass prairie, Long-term Ecological Research Network Series, Oxford University Press, New York, 364 pp., 1998.

Knapp, A. K., Briggs, J. M., and Koelliker, J. K.: Frequency and extent of water limitation to primary production in a mesic temperate grassland, Ecosystems, 4, 19-28, 2001.

Knapp, A. K., Fay, P. A., Blair, J. M., Collins, S. L., Smith, M. D., Carlisle, J. D., Harper, C. W., Danner, B. T., Lett, M. S., and McCarron, J. K.: Rainfall variability, carbon cycling, and plant species diversity in a mesic grassland, Science, 298, 2202-2205, 2002.

Knapp, A. K., Beier, C., Briske, D. D., Classen, A. T., Luo, Y., Reichstein, M., Smith, M. D., Smith, S. D., Bell, J. E., Fay, P. A., Heisler, J. L., Leavitt, S. W., Sherry, R. A., Smith, B., and Weng, E.: Consequences of more extreme precipitation regimes for terrestrial ecosystems, Bioscience, 58, 811-821, 2008.

Liu, W., Zhang, Z., and Wan, S.: Predominant role of water in regulating soil and microbial respiration and their responses to climate change in a semiarid grassland, Glob. Change Biol., 15, 184-195, 2009.

Luo, Y. Q. and Zhou, X.: Soil Respiration and the Environment, Academic Press, Burlington, VA, 320 pp., 2006.

Luo, Y. Q., Wan, S., Hui, D., and Wallace, L. L.: Acclimatization of soil respiration to warming in a tallgrass prairie, Nature, 413, 622-625, 2001.

McAllister, C. A., Knapp, A. K., Maragni, L. A.: Is leaf-level photosynthesis related to plant success in a highly productive grassland?, Oecologia, 117, 40-46, 1998.

Mielnick, P. C. and Dugas, W. A.: Soil $\mathrm{CO}_{2}$ flux in a tallgrass prairie, Soil Biol. Biochem., 32, 221-228, 2000.

Nippert, J. B. and Knapp, A.: Linking water uptake with rooting patterns in grassland species, Oecologia, 153, 261-272, 2007a.
Nippert, J. B. and Knapp, A. K.: Soil water partitioning contributes to species coexistence in tallgrass prairie, Oikos, 116, 10171029, $2007 \mathrm{~b}$.

Nippert, J. B., Fay, P. A., and Knapp, A. K.: Photosynthetic traits in $\mathrm{C}_{3}$ and $\mathrm{C}_{4}$ grassland species in mesocosm and field environments, Environ. Exp. Bot., 60, 412-420, 2006a.

Nippert, J. B., Knapp, A. K., and Briggs, J. M.: Intra-annual rainfall variability and grassland productivity: Can the past predict the future?, Plant Ecol., 184, 65-74, 2006 b.

Nippert, J. B., Fay, P. A., Carlisle, J. D., Knapp, A. K., and Smith, M. D.: Ecophysiological responses of two dominant grasses to altered temperature and precipitation regimes, Acta Oecol., 35, 400-408, 2009.

Noy-Meir, I.: Desert ecosystems: environment and producers, Annu. Rev. Ecol. Syst., 4, 25-51, 1973.

Ogle, K. and Reynolds, J. F.: Plant responses to precipitation in desert ecosystems: integrating functional types, pulses, thresholds, and delays, Oecologia, 141, 282-294, 2004.

Reynolds, J. F., Kemp, P. R., Ogle, K., and Fernandez, R. J.: Modifying the "pulse-reserve" paradigm for deserts of North America: precipitation pulses, soil water, and plant responses, Oecologia, 141, 194-210, 2004.

Rodriguez-Iturbe, I. and Porporato, A.: Ecohydrology of watercontrolled systems, Cambridge University Press, New York, 442 pp., 2004.

Rustad, L. E., Campbell, J. L., Marion, G. M., Norby, R. J., Mitchell, M. J., Hartley, A. E., Cornelissen, J. H. C., and Gurevitch, J.: A meta-analysis of the response of soil respiration, net nitrogen mineralization, and aboveground plant growth to experimentl ecosystem warming, Oecologia, 126, 543-562, 2001.

Saleska, S. R., Harte, J., and Torn, M. S.: The effect of experimental ecosystem warming on $\mathrm{CO}_{2}$ fluxes in a montane meadow, Glob Change Biol., 5, 125-141, 1999.

SAS Institute Inc.:The SAS System for Windows, SAS Institute, Cary, NC, 2003.

Schwinning, S. and Sala, O. E.: Hierarchy of responses to resource pulses in arid and semi-arid ecosystems, Oecologia, 141, 211220, 2004.

Sherry, R. A., Zhou, X., Gu, S., Arnone III, J. A., Schimel, D. S., Verburg, P. S., Wallace, L. L., and Luo, Y.: Divergence of reproductive phenology under climate warming, P. Natl. Acad. Sci., 104, 198-202, 2007.

Sherry, R. A., Weng, E., Arnone III, J. A., Johnson, D. W., Schimel, D. S., Verburg, P. S., Wallace, L. L., and Luo, Y.: Lagged effects of experimental warming and doubled precipitation on annual and seasonal aboveground biomass production in a tallgrass prairie, Glob. Change Biol., 14, 2923-2936, 2009.

Swemmer, A. M., Knapp, A. K., and Smith, M. D.: Growth responses of two dominant $\mathrm{C}_{4}$ grass species to altered water availability, Int. J. Plant Sci., 167, 1001-1010, 2006.

Trenberth, K. E., Jones, P. D., Ambenje, P., Bojariu, R., Easterling, D., Tank, A. K., Parker, D., Rahimzadeh, F., Renwick, J. A., Rusticucci, M., Soden, B., and Zhai, P.: Observations: Surface and Atmospheric Climate Change, in: Climate Change 2007: The Physical Science Basis (Contribution of Working Group I to the Fourth Assessment Report of the Intergovernmental Panel on Climate Change), edited by: Solomon, S., Qin, Q., Manning, M., Chen, Z., Marquis, M., Averyt, K. B., Tignor, M., Miller, H. L., Cambridge University Press, Cambridge, UK, 235-336, 
2007.

Turner, C. L., Kneisler, J. R., and Knapp, A. K.: Comparative gas exchange and nitrogen responses of the dominant C-4 grass Andropogon gerardii and five C-3 forbs to fire and topographic position in tallgrass prairie during a wet year, Int. J. Plant Sci., 156, 216-226, 1995.

Wan, S., Hui, D., Wallace, L. L., and Luo, Y. Q.: Direct and indirect effects of experimental warming on ecosystem carbon processes in a tallgrass prairie, Global Biogeochem. Cy., 19, 1-13, 2005.

Xia, J., Niu, S., and Wan, S.: Response of ecosystem carbon exchange to warming and nitrogen addition during two hydrologically contrasting growing seasons in a temperate steppe, Glob. Change Biol., 15, 1544-1556, 2009.
Zavaleta, E. S., Thomas, B. D., Chiariello, N. R., Asner, G. P., Shaw, M. R., and Field, C. B.: Plants reverse warming effect on ecosystem water balance, P. Natl. Acad. Sci., 100, 9892-9893, 2003.

Zhou, X., Sherry, R. A., An, Y., Wallace, L. L., and Luo, Y.: Main and interactive effects of warming, clipping, and doubled precipitation on soil $\mathrm{CO}_{2}$ efflux in a grassland ecosystem, Global Biogeochem. Cy., 20, GB1003, doi:10.1029/2005GB002526, 2006. 